University of Chicago Law School

Chicago Unbound

Journal Articles

Faculty Scholarship

1991

\title{
Should the Law Prohibit 'Manipulation' in Financial Markets?
}

Daniel R. Fischel

David J. Ross

Follow this and additional works at: https://chicagounbound.uchicago.edu/journal_articles

Part of the Law Commons

\section{Recommended Citation}

Daniel R. Fischel \& David J. Ross, "Should the Law Prohibit 'Manipulation' in Financial Markets?," 105 Harvard Law Review 503 (1991).

This Article is brought to you for free and open access by the Faculty Scholarship at Chicago Unbound. It has been accepted for inclusion in Journal Articles by an authorized administrator of Chicago Unbound. For more information, please contact unbound@law.uchicago.edu. 


\title{
SHOULD THE LAW PROHIBIT "MANIPULATION" IN FINANCIAL MARKETS?
}

\author{
Daniel R. Fischel and David J. Ross*
}

\section{INTRODUCTION}

Much of the regulation of financial markets seeks to prevent manipulation. The drafters of the Securities Act of $1933^{1}$ and the Securities Exchange Act of $1934,{ }^{2}$ for example, were convinced that there was a direct link between excessive speculation, the stock market crash of I929, and the Great Depression of the 1930s. Thus, section 2 of the Securities Exchange Act states:

National emergencies, which produce widespread unemployment and the dislocation of trade, transportation, and industry, and which burden interstate commerce and adversely affect the general welfare, are precipitated, intensified, and prolonged by manipulation and sudden and unreasonable fluctuations of security prices and by excessive speculation on such exchanges and markets .... ${ }^{3}$

Of particular concern to the drafters, as they repeatedly emphasized in the legislative history, were the well-publicized "pools" dating from the mid-nineteenth century in which perceived combinations of issuers, underwriters, and speculators, by their trading activities, allegedly caused wild fluctuations in security prices. ${ }^{4}$

* Lee and Brena Freeman Professor of Law, University of Chicago Law School

** Ph.D. candidate, University of Chicago Graduate School of Business; Vice President, Lexecon Inc.

The authors would like to thank Frank Easterbrook, William Landes, Louis Loss, Andrew Rosenfield, and seminar participants at the Law and Economics Workshops at Harvard University and the University of Chicago for valuable comments

1 Pub. L. No. 73-22, 48 Stat. 74 (codified as amended at 15 U.S.C. \$77a-77aa (I988))

2 Pub. L. No. $73-291,48$ Stat. 88 I (codified as amended at I5 U.S.C. $\$ 78 \mathrm{a}-78 l l$ (rg88))

${ }^{3}{ }_{5}$ U.S.C. $\$ 78 \mathrm{~b}(4)$ (1 988 ).

+ The legislative history of the securities laws, including the concern about the "pools," is exhaustively analyzed in Steve Thel, The Original Conception of Section ro(b) of the Securities Exchange Act, 42 STAN. L. REV. 385, 424-6I (1990) [hereinafter Thel, Original Conception]; and Steve Thel, Regulation of Manipulation Under Section $I O(b)$ : Security Prices and the Text of the Securities Exchange Act of 1934, 1988 CoLum. Bus. L. REv. 359, 362-82 [hereinafter Thel, Manipulation Under Section ro(b)]. See also Twentieth Century Fund, Inc., The Security Markets 445 (Alfred L. Bernheim \& Margaret G. Schneider eds., 1935) ("[T]he more important [manipulative] market campaigns . . . are the work of groups organized into syndicates, pools or joint accounts."); Norman S. Poser, Stock Market Manipulation and Corporate Control Transactions, 40 Miami L. REv. 671, 69I (1986) ("Beginning at least as early as the middle of the nineteenth century and continuing until the very time that Congress considered 
To curtail the pools and related speculative excesses, Congress proscribed certain trading practices deemed to be manipulative. Among the practices so classified were wash sales, ${ }^{5}$ matched orders, ${ }^{6}$ short sales, ${ }^{7}$ and a more amorphous practice believed to be characteristic of the pools - trading in a security "for the purpose of inducing the purchase or sale of such security by others." 8 The statutory provisions governing these practices were designed "to purge the securities exchanges of those practices which have prevented them from fulfilling their primary function of furnishing open markets for securities where supply and demand may freely meet at prices uninfluenced by manipulation or control."

The regulation of futures markets also reflects concern about the dangers of manipulation. For example, the Grain Futures Act of $1922,{ }^{10}$ one of the first federal statutes governing futures markets, had as a core premise that futures prices "are susceptible to speculation, manipulation, and control." 11 Similarly, the stated purpose of the Futures Trading Act of $1982,{ }^{12}$ which amended the Grain Futures Act, ${ }^{13}$ was "to . . . provide a measure of control over manipulative activity and speculative excesses that demoralize the market to the injury of producers and consumers and the exchanges themselves." 14

the bill that was to become the Exchange Act, the most important market manipulations were the work of groups of speculators known as pools.").

${ }^{5}$ See 15 U.S.C. $\$ 78 \mathrm{i}(\mathrm{a})(\mathrm{I})(\mathrm{A})$ (1988) (defining wash sales as security transactions in which the parties intend for there to be no actual change in beneficial ownership).

${ }^{6}$ See id. $\$ 78 \mathrm{i}(\mathrm{a})(\mathrm{I})(\mathrm{B})$, (C) (defining matched orders as orders entered for the purchase or sale of a security "with the knowledge that an order or orders of substantially the same size, at substantially the same time, and at substantially the same price... have been or will be entered by or for the same or different parties").

'See id. $\$ 78 \mathrm{j}$ (a) (making it "unlawful for any person ... . [t]o effect a short sale" in contravention of rules adopted by the Securities and Exchange Commission).

${ }^{\sharp} I d . \$ 78 \mathrm{i}(\mathrm{a})(2)$. This provision has been described as "the very heart" of the securities acts. Louis Loss, Fundamentals of Securities Regulation 853 (2d ed. 1988) (quoting SEC, Report on Proposals for Amendments to the Securities Act of 1933 and the SecuRities Exchange ACt of r 934, at 50 (H.R. Comm. Print I941))

4 Senate Comm. on Banking and Currency, Stock Exchange Practices, S. Rep. No. 1455, 73d Cong., 2d Sess. 30 (1934) (the "Fletcher Report"), reprinted in 5 LEGISLATIVE History of The Securities ACT of 1933 AND Securities Exchange Act of 19.34, at Item No. 2 I (J. S. Ellenberger \& Ellen P. Maher eds., r973).

10 Pub. L. No. 67-33I, 42 Stat. 998 (I922) (codified as amended at 7 U.S.C. $\$ \$$ I-26 (I988)).

11 Id. $\S 3,42$ Stat. at 999 . This section was amended by Pub. L. No. 97-444, 96 Stat. 2294 (I983), to read, "are susceptible to excessive speculation and can be manipulated, controlled, cornered or squeezed, to the detriment of the producer." Id., 96 Stat. at 2298.

12 Pub. L. No. 97-444, 96 Stat. 2294 (1983) (codified as amended at 7 U.S.C. $\$ \$ 1-26$ (1988))

13 The Grain Futures Act had been renamed the Commodity Exchange Act, Pub. L. No. 49-675, 49 Stat. 149I (I936) (codified as amended at 7 U.S.C. $\$ \$$ I-26 (I988)).

14 Senate Comm. on Agriculture, Nutrition, and Forestry, 95Th Cong., 2 D Sess., Futures Trading ACT of 1978, at ${ }_{3} 6$ (Comm. Print 1979). See generally S. ReP. No. 850, 95th Cong., 2d Sess. 5-13 (1978) (summarizing the history of the Commodity Futures Trading Commission). 
The Act requires that all boards of trade designated as contract markets prevent the "manipulation of prices and the cornering of any commodity by the dealers or operators upon such board." 15

Recent events have dramatically increased interest in the concept of manipulation in financial markets. The widely publicized criminal prosecutions of Michael Milken, Drexel Burnham Lambert, Ivan Boesky, Dennis Levine, Boyd Jefferies, the GAF Corporation and James Sherwin, Salim "Sandy" Lewis, Paul Bilzerian, and others all involved allegations of manipulation of securities markets. ${ }^{16}$ More generally, the stock market crash of October 1987 raised anew the question whether certain trading practices, such as program trading, manipulated the market by causing a severe decline in securities prices. ${ }^{17}$

The story is much the same in futures markets. The Hunt brothers acquired massive amounts of silver and silver futures contracts in the late I970s and early 1980s. This acquisition activity, coupled with a precipitous worldwide rise and later collapse in the price of silver, led to a decade of litigation and governmental investigations centered on the claim that the Hunts had manipulated silver prices by cornering the futures market in silver. ${ }^{18}$ Another area of considerable controversy has been the proliferation of new instruments such as stock index futures contracts. The Commodity Futures Trading Commission, the Securities and Exchange Commission, and the Federal Reserve Board have actively scrutinized whether such contracts are more susceptible to manipulation than traditional futures contracts. ${ }^{19}$

\footnotetext{
157 U.S.C. $\$ 7$ (d) (1988).

${ }^{16}$ For an overview of these recent cases and the law of manipulation in general, see Arthur F. Mathews, Theodore A. Levine, Girard Citera \& David Dana, Manipulative Practices: Past, Present and Future, in Trading Practices, the Portrolio Execution Process, and Soft Dollar Practices I990, at 99, I67-87 (Practising Law Institute ed., r990) [hereinafter Manipulative Practices].

17 For a discussion of the relationship between concern over the role of program trading after the October 1987 crash with the analogous concern over the role of short sales after the October 1929 crash, see Jonathan R. Macey, Mark Mitchell \& Jeffry Netter, Restrictions on Short Sales: An Analysis of the Uptick Rule and Its Role in View of the October 1087 Stock Market Crash, 74 CORNELL L. REV. 799 (I989) [hereinafter Restrictions on Short Sales]

${ }^{18}$ See Minpeco, S.A. v. Conticommodity Servs., Inc., 832 F.2d 739, 740 (2d Cir. 1987) ("[I]n 1979 and $1980 \ldots$ the Hunts allegedly attempted to corner the silver market and reap enormous profits thereby."); Korwek v. Hunt, 827 F.2d 874, 875 (2d Cir. 1987) (discussing "an alleged conspiratorial manipulation of the silver futures market and the concomitant well-publicized plummet of silver and silver futures prices"); $c f$. Reauthorization of the Commodity Futures Trading Commission: Hearings Before the Subcomm. on Agricultural Research and General Legislation of the Comm. on Agriculture, Nutrition, and Forestry, 95th Cong., 2d Sess., pt. 2, at $157-69,470-80$ ( 1978 ) (describing the Hunts' position in the soybean market).

${ }^{19}$ For an analysis of this issue, see Linda N. Edwards \& Franklin R. Edwards, A Legal and Economic Analysis of Manipulation in Futures Markets, 4 J. FUTURES MARKeTs 333, 35961 (1984); and Daniel R. Fischel, Regulatory Confict and Entry Regulation of New Futures Contracts, $59 \mathrm{~J}$. Bus. S85 (1986).
} 
Notwithstanding the recent focus on manipulation, however, no satisfactory definition of the term exists. ${ }^{20}$ Indeed, neither the Securities Exchange Act nor the Commodity Exchange Act attempts to define the term, even though both have the prevention of manipulation as a primary goal. Academic commentary in this area also has been unhelpful. ${ }^{21}$ An inability to define a type of prohibited conduct frequently reflects conceptual confusion, and the concept of manipulation is no exception. ${ }^{22}$ As one commentator has noted, "the law governing manipulations has become an embarrassment - confusing, contradictory, complex, and unsophisticated."23

This article attempts to provide what the existing literature lacks - a principled analysis of the concept of manipulation. We begin, in Part II, by exploring existing definitions of manipulation. These definitions focus on concepts such as interference with the legitimate forces of supply and demand and the creation of artificial prices. We demonstrate that these concepts are meaningless and conclude that there is no objective definition of manipulation - manipulative trades must be defined with respect to the intent of the trader. Part III analyzes the critical difference between actual and phony trades and discusses the distinction between fraud and manipulation.

Part IV considers whether the possibility of "trade-based" manipulations (schemes in which profits are obtained from the trades themselves) provides a rationale for legal rules that prohibit actual trades based on the intent of the trader. Part $\mathrm{V}$ addresses manipulative schemes other than trade-based schemes. In these sections we discuss the difficulty of identifying manipulative conduct through objective means, the low probability that trade-based manipulations can succeed and hence the self-deterring nature of manipulations, and the ability of market participants to deal with the problem by contract. Together, Parts II through V provide the conceptual core of our analysis.

Part VI discusses three prominent recent examples of alleged manipulations. Parts VII through IX then apply our analysis to other areas of the law. Part VII examines the law regulating distributions. Part VIII discusses the regulation of markups charged by brokers in

20 See Loss, supra note 8 , at $860 \mathrm{n} .75$ (“[T] he word 'manipulative' as used in $\S \S \mathrm{ro}(\mathrm{b})$ and $15(c)(1)$ has never had any precise meaning . . . .).

21 The best existing treatment of the concept of manipulation is Frank $H$. Easterbrook, Monopoly, Manipulation, and the Regulation of Futures Markets, 59 J. Bus. Sro3 (1986). As we demonstrate below, however, Judge Easterbrook's analysis, which focuses on futures markets, accepts the validity of the concept of manipulation as a premise and contains many of the same flaws found in more conventional treatments of the subject.

22 Insider trading is another example of this phenomenon. Cf. Dennis W. Carlton \& Daniel R. Fischel, The Regulation of Insider Trading, 35 STAN. L. REv. 857, 860 61 (I983) (discussing the differences between the legal and economic definitions of "insider trading").

${ }^{23}$ Edward T. McDermott, Defining Manipulation in Commodities Futures Trading: The Futures "Squeeze," 74 Nw. U. L. REV. 202, 205 (1979). 
secondary transactions. Finally, Part IX applies our analysis to the problem of corners and squeezes in futures markets.

In a sharp departure from current law and commentary, we conclude that the concept of manipulation should be abandoned altogether. Fictitious trades should be analyzed as a species of fraud. Actual trades should not be prohibited as manipulative regardless of the intent of the trader.

\section{The Definition of Manipulation}

Although manipulation is defined nowhere in regulatory statutes, courts and commentators have suggested various formulations. One common approach is that if "manipulation means anything in particular, it means conduct intended to induce people to trade a security or force its price to an artificial level."24 Alternatively, manipulation has been defined as "deliberate interference with the free play of supply and demand in the security markets." 25 According to these definitions, conduct is manipulative if it is designed to do one of three things: (I) interfere with the free play of supply and demand; (2) induce people to trade; or (3) force a security's price to an artificial level. It is useful to consider each of these elements separately.

The first formulation (interference with the free play of supply and demand) is unhelpful because the term "interference" is undefined. Presumably, manipulative conduct constitutes "interference," but this is circular absent a definition of manipulation. Moreover, all traders are part of the forces of supply and demand. The concept of manipulation assumes some traders have legitimate demand for a security while others do not. But again, absent a definition that distinguishes between legitimate and illegitimate demand, the concept of interference with supply and demand does not advance the inquiry.

The second formulation (inducing others to trade) is in one sense an improvement over the first formulation because the former identifies a particular type of conduct that should be deterred. Indeed, the "inducement of trading . . . is sometimes said to be the essence of manipulation." 26 The problem with this definition of manipulation is that it is hopelessly overbroad - it includes value-maximizing exchanges in which the transaction makes each party better off. If A, by making an offer to B that B accepts, "induces" B to enter into a transaction that makes both better off, this cannot be "manipulation." It is irrelevant whether the subject of the transaction is a

\footnotetext{
24 Thel, Original Conception, supra note 4, at 39.3 ; see also id. at 393 n. 36 (collecting a long list of authoritjes adopting this approach).

25 Twentieth Century Fund, Inc. Stock Market Control 107 (Alfred L. Bernheim, Evans Clark, J. Frederick Dewhurst \& Margaret G. Schneider eds., 1934).

26. Thel, Manipulation Under Section ro(b), supra note 4 , at 4 ro.
} 
security. Traders may have different estimates about the value of a security, different tolerances for risk, or different liquidity needs. Trades may be mutually beneficial in any of these situations.

Firms may also act to induce trades. For example, a firm might engage in one of a variety of signalling devices - such as purchasing its own shares or changing its capital structure or dividend policy as a way of communicating information about the value of its securities. ${ }^{27}$ Alternatively, the firm might disclose new information about the value or riskiness of its securities directly to investors. All of these actions will likely lead to increases in the volume of trading and thus can be said to have "induced" trading.

The trading in the above examples has the common characteristic of being for some purpose, such as repricing securities in light of new information, portfolio rebalancing, or liquidity. Perhaps manipulation is conduct that induces investors to trade for no purpose. But this definition is also problematic. How can investors be "induced" to trade (and incur transaction costs in the process) for no purpose? And what categories of trades have no purpose? Existing definitions of manipulation provide no answers to these questions and thus provide no guidance on the distinction between beneficial and non-beneficial trades.

The third formulation (forcing security prices to an artificial level) has intuitive appeal because creation of artificial prices, unlike trading, is socially undesirable. For this formulation to be operational, however, one must be able to define the difference between an artificial and a non-artificial price. This task turns out to be much more difficult than it might at first appear.

One possible definition is that any price change that results from trading designed to produce such a price change is an artificial price. This definition is unsatisfactory because trading with the purpose of producing a price change is not necessarily harmful. Consider again the example of an issuer that purchases its own shares to signal investors that the shares are undervalued. In this example, the trading moves prices in the correct direction and thus the resulting price change should not be labeled "artificial."

\footnotetext{
2i Studies of share repurchases are consistent with the hypothesis that firms offer premia for their own shares in order to signal positive information. See Larry Y. Dann, Common Stock Repurchases: An Analysis of Returns to Bondholders and Stockholders, 9 J. Fin. Econ. I13, I16-36 (1981); Theo Vermaelen, Common Stock Repurchases and Market Signalling: An Empirical Study, 9 J. FIN. ECON. I39, I59-7 I (1981). Similarly, studies of dividend changes find that announcements of such changes provide useful information to market participants. See, e.g., Joseph Aharony \& Itzhak Swary, Quarterly Dividend and Earnings Announcements and Stockholders' Returns: An Empirical Analysis, 35 J. FIN. I, I I (1980) ("[Qjuarterly cash dividends provide useful information beyond that provided by corresponding quarterly earnings numbers.").
} 
An alternate approach is to focus on whether the trading moves prices closer to or away from their correct level. But what is the "correct level"? One possibility is the price that reflects long-run conditions of supply and demand. Manipulation could then be defined as trades that "do not move price more quickly in the direction that reflects long-run conditions of supply and demand."28 Judge Frank Easterbrook has suggested this definition of manipulation. But this definition is also unsatisfactory. What if the trades do not move prices at all or move prices in the direction that reflects short-run conditions of supply and demand? Most importantly, what happens if the trades move prices in one direction because the trader genuinely believes that prices will move in this direction, but the trader turns out to be wrong and prices ultimately move in the opposite direction? Trading based on a genuine belief that prices will ultimately move in the direction of the trades is the essence of nonmanipulative trading.

To avoid the need to distinguish between short-run and long-run conditions of supply and demand, the correct level of prices could be defined as the level prices would be if all relevant information were publicly disclosed. But this definition is also unhelpful. "All relevant information" includes not only the information possessed by the trader, but also the trades themselves. If prices move in response to trades, the price cannot be said to be "artificial" unless the trades are defined as illegitimate in some way. Once again we are faced with the problem of circularity - improper trades are trades that produce an artificial price and artificial price is defined as a price produced by improper trades.

Defining manipulation by reference to whether the trades move prices closer to their correct level has another flaw: it jeopardizes property rights in information. Absent a fiduciary relationship or other special circumstance, traders do not have a duty to disclose the information they possess that motivates their trades. ${ }^{29}$ Disclosure would cause the information to lose its value and thus eliminate the incentive to acquire the information in the first place. Without such an incentive, no one would search for information and securities markets - which depend on new information to cause price changes - would be destroyed. But trades, as well as disclosures, can reveal information. The more information the trade reveals, the closer the trade comes to a direct disclosure, which decreases the trader's ability to capture the value of the private information in his possession. For markets to exist, therefore, trades cannot be fully revealing. ${ }^{30}$ Traders

2x See Easterbrook, supra note 2I, at Si 18.

29 See, e.g., Chiarella r. United States, 445 U.S. 222,230 ( 1980 ) (holding that there is no duty to disclose absent "a relationship of trust and confidence between [the] parties to a transaction").

3) See, e.g., Sanford Grossman, On the Efficiency of Competitive Stock Markets Where 
must be allowed to disguise their trades to avoid disclosing the information they possess to other traders. Accordingly, manipulation cannot be defined as trading that does not move prices closer to their "correct" level. Such a definition would deny traders the ability to disguise their trades to capture the value of the information they possess.

Thus, there is no objective definition of manipulation. The only definition that makes any sense is subjective - it focuses entirely on the intent of the trader. Manipulative trades could be defined as profitable trades made with "bad" intent - in other words, trades that meet the following conditions: ( $\mathrm{r}$ ) the trading is intended to move prices in a certain direction; (2) the trader has no belief that the prices would move in this direction but for the trade; and (3) the resulting profit comes solely from the trader's ability to move prices and not from his possession of valuable information. Traders who trade with "good" intent - for the purpose of moving prices in the direction they believe prices will move - are not engaged in manipulation. Similarly, traders with private information who disguise their trades with the effect that prices do not move in the correct direction, or even move in the wrong direction, also trade with "good" intent and thus are not engaged in manipulation because their ultimate profit is attributable to the private information they possess.

\section{Manipulation Compared with Fraud}

The relationship between manipulation and fraud has never been clear. Judge Frank Easterbrook has stated that manipulation is a species of fraud. ${ }^{31}$ Another commentator has posited that manipulation is "[r]elated to the field of fraud - but not altogether a part of it as a matter of legal analysis." 32 Precisely how manipulation is related to fraud, and how it is different, has never been analyzed.

For certain types of conduct, manipulation is best understood as a species of fraud. For example, fictitious transactions - wash sales or matched orders - are designed to mislead market participants into believing that buyers and sellers are trading in a security when in fact no transactions are taking place. Such transactions are a form of fraud by conduct. Indeed, the concept of manipulation for this category of cases is superfluous. The concept of fraud is sufficient. ${ }^{3.3}$

Trades Have Diverse Information, 31 J. Fin. 573, 585 (1976) ("The price system can be maintained only when it is noisy enough so that traders who collect information can hide that information from other traders.").

"See Easterbrook, supra note 21, at Sro6 "'Monopoly' in a futures market. . turns out to be a species of fraud.").

32 Loss, supra note 8 , at 84.3 .

3.3 This was recognized at common law in the nineteenth century. See Scott $v$. Brown, 
Defining manipulation as a species of fraud does not work as well in situations involving actual, as opposed to fictitious, trades. ${ }^{34}$ Consider the example of a trader who trades with "bad" intent - he attempts to affect the price with no belief that the price would otherwise move in this direction. Would such a trader be deemed to have engaged in fraud? It could be argued that the trader has engaged in fraud by acting (that is, trading) for the purpose of misleading market participants about the true value of the security. But there is a critical difference between the typical fraud and the trading in this example. The typical fraud involves a bad act (a false statement) as well as an intent to defraud. ${ }^{35}$ In the fraud case, the intent question becomes relevant only when there is a bad act as determined by an objective test - whether the statement is false. Furthermore, one can argue, the law is concerned only with conduct objectively determined to be wrongful. Absent wrongful conduct, there is no harm and no loss - true statements are never punished. Hence, unless a statement is false, no need exists to examine the speaker's intent.

Thus, the trader in the above example presents a very different case from the one engaging in fictitious trades or making false statements, because the former has not engaged in any conduct that can be objectively determined to be socially undesirable. The only act is trading, trading that cannot be distinguished from other trading using objective measures. The only distinction is the intent of the trader. In the case of manipulation, in other words, whether conduct is bad depends entirely on the intent of the trader. In the case of fraud, by contrast, whether conduct is undesirable depends on objective criteria - whether there has been a false statement - and not solely on the speaker's intent.

At first blush, this difference between fraud and manipulation disappears in cases of nondisclosure as opposed to cases involving

Doering, McNab \& Co., [1892] 2 Q.B. 724, 730 (C.A.) (finding "no substantial distinction between false rumours and false and fictitious acts"). The Scott case was cited in Schreiber v. Burlington Northern, Inc., 472 U.S. I ( 1985$)$, to support the proposition that manipulation at common law required a showing of deception. See id. at $;$ n.4. The Supreme Court in recent years has held that the term manipulation under the securities laws requires deception. See id. at $\delta$ (holding "that 'manipulative' acts under \$ I $4(\mathrm{e})$ [of the Securities Exchange Act] require misrepresentation or nondisclosure"); Santa Fe Indus. v. Green, 430 U.S. 462, 476 (I 977) (holding that the term "manipulative" in $\$ I O(b)$ of the Securities Exchange Act "refers generally to practices, such as wash sales, matched orders, or rigged prices, that are intended to mislead investors by artificially affecting market activity").

${ }^{34}$ See Poser, supra note 4, at 699 (concluding, after surveying the common law, that "[t]he effecting of actual transactions for the purpose of influencing its price by inducing others to buy or sell a security, though commonly viewed as manipulative, remained legal in the United States until the enactment of the Exchange Act").

35 See, e.g., Restatement (SEcond) of TorTs $\$ 525$ (1976) (defining fraud as, in part, "a misrepresentation of fact, opinion, intention or law for the purpose of inducing another to act or to refrain from action"). 
false statements. Because failure to disclose, like trading, is an ambiguous act, it could be argued that nondisclosure cases are similar to manipulation cases. But the analogy breaks down upon closer analysis. Nondisclosure in law is actionable only when there is a duty to speak arising from objectively observable criteria, such as the relationship between the parties. ${ }^{36}$ Absent such a duty to speak, there can be no actionable nondisclosure, regardless of the intent of the alleged wrongdoer. Once again, in fraud, but not in manipulation, whether the act is wrongful does not depend solely on the intent of the alleged perpetrator.

There is a second difference between fraudulent conduct and actual trades with bad intent. Legal rules are needed more to deter fraud than to deter actual trades with bad intent. False statements (putting aside reputational effects) are not self-deterring. Such statements frequently require trivial or no capital investment. Absent a legal rule requiring, for example, disgorgement of gains or compensation for losses, fraud can be highly profitable. This is much less the case with actual trades, as we discuss immediately below.

\section{Should Legal Rules Prohibit Actual Trades BASED ON THE INTENT OF THE TRADER?}

As we have seen, there is no objective definition of manipulation. Everything turns on the intent of the trader. The question then arises whether legal rules should ever attempt to prevent actual trades made with "bad" or manipulative intent. To answer this question one must assess the relative social costs and benefits of a legal rule of prohibition compared with a rule of no prohibition.

\section{A. The Probability of Successful Manipulation}

One relevant inquiry in analyzing the desirability of a legal prohibition is the likelihood that the conduct will occur in the absence of a prohibition. In the case of manipulation, the likelihood is extremely low.

Traders will attempt to manipulate the price of a security only when they believe it is profitable to do so. Profitable (successful) manipulations require two conditions: first, trading must cause the price of the relevant security to rise; and second, the manipulator must be aple to sell at a price higher than the price at which the manipulator purchased (plus transactions costs incurred). If the first condition is not met, no possibility of profit exists because the manipulator will be purchasing and selling at the market price and incurring transactions costs in the process. Similarly, if the second condition is

\footnotetext{
${ }^{36}$ See Chiarella v. United States, 445 U.S. 222,232 (1980).
} 
not met, no possibility of profit exists because the proceeds received in sale will not exceed the proceeds expended in purchase.

It is extremely difficult to satisfy both conditions simultaneously. In most cases, anonymous trades will have no effect on security prices, a violation of the first condition. To satisfy this condition, the manipulator will have to convince other traders that he has information about the value of the security they do not have, or he will have to expend huge amounts of capital. The consequence of this strategy, however, is that the price of the relevant security is likely to rise simultaneously with the trades but not to rise thereafter, a violation of the second condition. Thus, the basic dilemma of the prospective manipulator is to seem informed enough to cause prices to rise by purchasing, but not so informed as to cause the price to rise simultaneously with purchase. Also, he must not appear informed at the time of sale, lest his sales cause the price to fall. The relationship between trading and price movements thus creates an intractable dilemma for the potential manipulator.

I. The Relationship Between Trading and Price Movements. Most discussions of manipulation assume that there is a direct relationship between trading and price movements. ${ }^{37}$ Because purchases increase the demand for a security and sales increase the supply, it is commonly assumed that trading affects securities prices. But the actual relationship between trading and price movements is far more complex.

The relationship between demand and supply shifts and securities prices depends on the elasticity of demand and supply. ${ }^{38}$ When supply (demand) is relatively elastic, an increase in demand (supply) need not affect price. ${ }^{39}$ Portfolio theory provides powerful reasons to believe that demand and supply are elastic. Investors hold securities to obtain

${ }^{37}$ This was clearly the assumption of the drafters of the securities acts, who believed that purchases raised prices and sales depressed them. See, e.g., S. REP. No. 792, 73d Cong., $2 \mathrm{~d}$ Sess. 7-9 (I934), reprinted in 5 Legislative History of THE SECURITIEs ACT OF I933 AND Securities Exchange Act of 1934, at Item No. I7 (J. S. Ellenberger \& Ellen P. Mahar eds., I 973).

${ }^{38}$ Elasticity refers to the percentage change in quantity demanded or supplied for a given change in price. To illustrate, if demand decreases by $10 \%$ when price increases by $10 \%$, then the elasticity of demand is - 1 . Similarly, if supply increases by 10\% when price increases by $10 \%$, then the elasticity of supply is 1 . The relevant elasticity for determining how an increase in demand would affect price is the elasticity of supply, because this elasticity determines how much of a premium buyers must offer to induce suppliers to provide the additional quantity demanded.

${ }^{39}$ Even when supply and demand are relatively inelastic, most transactions will not affect price because they are too small. Consider a security with a demand elasticity of only -.5 (a $1 \%$ increase in supply causes a $2 \%$ decline in price). Assume further that there are ro million shares outstanding. In these circumstances, the sale of an additional I, ooo shares would cause prices to decline by only $0.02 \%$. In other words, most buyers and sellers would still behave as price-takers no matter what the elasticity of supply and demand. 
a stream of future income that can be used to finance future consumption and investment. ${ }^{40}$ To achieve this goal, they can choose from many possible combinations of available assets. ${ }^{41}$ Because it is possible to find substitute assets that closely replicate the expected stream of income provided by any particular security, the supply of near-perfect substitutes for any particular security is likely to be much larger than the supply of the security itself. ${ }^{42}$ The availability of close substitutes means that an investor seeking to purchase a particular security should be able to convince current holders to sell the security at the current market price. ${ }^{43}$ Thus, theoretically, trading need not have any effect on securities prices. This proposition is known as the substitution hypothesis. ${ }^{4}$

Considerable empirical evidence supports the substitution hypothesis. Millions of shares of listed securities are traded every day with no change in the market price. Studies of situations such as primary and secondary offerings in which large amounts of securities are sold (an increase of supply) have typically concluded that there is no per se relationship between the size of the offering and price movements. ${ }^{45}$ Similarly, a high percentage of block trades occurs at the existing market price. ${ }^{46}$

The substitution hypothesis posits that the demand and supply for securities are sufficiently elastic that trading by itself need not affect security prices. This does not mean, however, that no relationship exists between trading and price. Investors who obtain information that leads them to believe that a security is underpriced will want to

40 Most models of capital market equilibrium pricing imply that individual securities have good substitutes. See, e.g., Robert C. Merton, An Intertemporal Capital Asset Pricing Model, 4I Econometrica 867 (I973); William F. Sharpe, Capital Asset Prices: A Theory of Market Equilibrium Under Conditions of Risk, I9 J. FIN. 425, 429 (I964)

${ }^{4}$ See Myron S. Scholes, The Market for Securities: Substitution Versus Price Pressure and the Effects of Information on Share Prices, $45 \mathrm{~J}$. BUS. 179, 181 (1972).

42 See id at $181-82$

43 See id. at 206

44 See id. at $181-82$.

45 For the evidence on new equity issues, see Alan C. Hess \& Peter A. Frost, Tests for Price Effects of New Issues of Seasoned Securities, 37 J. Fin. 11, 24 (1982); Richard Kolodny \& Diane R. Suhler, Changes in Capital Structure, New Equity Issues, and Scale Effects, 8 J. Fin. RES. I27, I35 (I985) (attributing negative returns to transaction costs, tax effects, and new unfavorable information); and Richard H. Pettway \& Robert C. Radcliffe, Impact of New Equity Sales upon Electric Utility Share Prices, I4 FIN. MGMT. I6, 24 (I985). Secondary distributions are considered in Paul Asquith \& David W. Mullins, Jr., Equity Issues and Offering Dilution, I5 J. Fin. Econ. 61, 77-79 (1986); Wayne H. Mikkelson \& M. Megan Partch, Stock Price Effects and Costs of Secondary Distributions, I4 J. FiN. Econ. 165, I92-94 (1985); and Scholes, supra note 41 , at $198-99$. Asquith and Mullins find results consistent with both the information hypothesis and the price pressure hypothesis. See Asquith \& Mullins, supra, at 82

${ }^{46}$ See Robert E. Holthausen, Richard W. Leftwich \& David Mayers, The Effect of Large Block Transactions on Security Prices: A Cross-Sectional Analysis, I9 J. Fin. Econ. 237, 24546 (1987) [hereinafter Large Block Transactions]. 
buy it. Other investors who receive information leading them to believe that a security is overpriced will want to sell it. The buying and selling activity of these market participants may reveal the information they have and cause prices to adjust accordingly. Such adjustment will result in a relationship between trading and price movements.

Put differently, the price of a security at any point in time depends on the value investors expect it will provide in the future. That future value is uncertain. Investors who obtain information that the future value is high relative to today's price will want to buy. Their purchases, however, may lead other market participants to revise upward their expectations about the value of the security and thus cause its price to rise. Because the market price is a function of the information available, trading may affect the market price by providing market participants with additional information. This is known as the information hypothesis. ${ }^{47}$

Many studies support the information hypothesis as well. Announcements of intentions by traders believed to be informed can have significant consequences for stock prices. This is true both for potential acquirors ${ }^{48}$ and for issuers or underwriters in the case of primary equity offerings ${ }^{49}$ or secondary distributions. ${ }^{50}$ Similarly, many block trades have stock price consequences. ${ }^{51}$

Trading can result in price changes for another reason: liquidity costs. $^{52}$ An investor who wants to buy or sell a large quantity of shares immediately may be unable to do so at the market price because at that moment there are not enough market participants willing to

\footnotetext{
47 See, e.g., Asquith \& Mullins, supra note 45, at 62; Kolodny \& Suhler, supra note 45, at $128-29$.

${ }^{48}$ See, e.g., Clifford G. Holderness \& Dennis P. Sheehan, Raiders or Saviors? The Evidence on Six Controversial Investors, 14 J. Fin. ECoN. 555, 577 (1985).

${ }^{49}$ A typical finding is that announcements of primary equity offerings are associated with stock price declines that average about three percent. These declines are usually attributed to an information effect. See Asquith \& Mullin, supra note 45, at 66; Kolodny \& Suhler, supra note 45, at 135; Pettway \& Radcliffe, supra note 45, at 22-24; see also Avner Kalay \& Adam Shimrat, Firm Value and Seasoned Equity Issues: Price Pressure, Wealth Redistribution, or Negative Information, I9 J. FIN. ECON I09, I 25 (I987) (citing empirical evidence that new equity issues by industrial companies are associated with a drop in stock price); Ronald $\mathrm{W}$. Masulis \& Ashok N. Korwar, Seasoned Equity Offerings: An Empirical Invest،yation, I5 J. FIN. ECoN. $9 \mathrm{I}$, I I 6 (I986) (documenting a significant decrease in the value of common stock on the announcements of primary and combination stock offerings); Katherine Schipper \& Abbie Smith, A Comparison of Equity Carve-Outs and Seasoned Equity Offerings: Share Price Effects and Corporate Restructuring, i5 J. FIN. ECoN. 153, 181 (1986) (concluding that announcements of public offerings of parent common stock are associated with shareholder losses).

50 See Asquith \& Mullins, supra note 45, at 70-74; Scholes, supra note 4I, at 203-04.

51 See Alan Kraus \& Hans R. Stoll, Price Impacts of Block Trading on the New York Stock Exchange, 27 J. FIN. 569, 587-88 (1972); Large Block Transactions, supra note 46, at $238-39$, $252-54,264$.

52 See Pettway \& Radcliffe, supra note 45 , at 16
} 
take the other side of the trade. ${ }^{53}$ To induce others to participate, a buyer (seller) may have to pay a premium (sell at a discount). Such premiums (discounts) compensate intermediaries for the costs of maintaining a short (long) position until another investor willing to sell (buy) can be found. This is known as the liquidity hypothesis. ${ }^{54}$

To some extent, all traders, large and small, bear such liquidity costs because there is no single price at which securities trade. ${ }^{55}$ The activities of specialists or other market makers, and the placement of limit orders by customers, create two prices at any point in time: the bid price and the ask price. ${ }^{56}$ The bid price is the highest available price at which a customer can sell a particular security and the ask price is the lowest available price at which a customer can buy a security.

The existence of a bid-ask spread necessarily results in a relationship between trading and price. ${ }^{57}$ To see why, suppose that a particular security always has a fixed bid price of $\$ 9$ and a fixed ask price of $\$ \mathrm{I}$ o. All customer buy orders are executed at $\$ \mathrm{IO}$; all customer sell orders are executed at $\$ 9$. If the last executed transaction was a customer sale, a buy order will cause the observed price to increase (from $\$ 9$ to $\$ \mathrm{I} 0$ ). Conversely, if the last executed transaction was a customer buy, a sell order will cause the observed price to decrease (from \$ro to \$9). Sequential transactions on the same side will not result in price changes, but sequential transactions on different sides will. As buy and sell orders arrive randomly, some purchases will follow sales and some sales will follow purchases. These will cause temporary price changes: on average, buy orders will be associated with price increases and sell orders will be associated with price decreases until these price changes are reversed by trades on the other side of the bid-ask spread. ${ }^{58}$

Finally, trading can cause price changes if the demand and supply for securities are not perfectly elastic. This possibility is referred to as the price pressure hypothesis. ${ }^{59}$ This hypothesis posits that securities possess unique characteristics and perfect substitutes do not exist; therefore, increases in supply or demand can cause price changes.

\footnotetext{
5.3 See id.

st see id.

55 See Victor Niederhoffer \& M.F.M. Osborne, Market Making and Reversal on the Stock Exchange, 61 J. AM. STAт. Ass'N 897, 905 (1966).

st See id. at g04-05.

st See id.; Richard Roll, A Simple Implicit Measure of the Effective Bid-Ask Spread in an Efficient Market, 39 J. FiN. I I 27, I I $28-29$ (1984).

58 See Niederhoffer \& Osborne, supra note 55, at 905 .

59 See, e.g., Christopher G. Lamoureux \& James W. Wansley, Market Effects of Changes in the Standard and Poor's 500 Index, 22 Fin. REv. 53, 55 (1987); J. Randall Woolridge \& Chinmoy Ghosh, Institutional Trading and Security Prices: The Case of Changes in the Composition of the $S \mathcal{E} P$; 500 Index, 9 J. FIN. RES. I3, 15 (I986).
} 
Unlike the temporary price changes associated with the bid-ask spread, price changes resulting from price pressure are permanent. Several recent studies analyzing the effect of additions to or deletions from the Standard and Poor's (S\&P) 500 Index provide some support for the price pressure hypothesis. ${ }^{60}$ These studies find significant stock price reactions to the announcement of an addition to or deletion from the index. ${ }^{61}$ One interpretation of this result is consistent with the price pressure hypothesis: the addition (deletion) of a security to (from) the S\&P 500 Index causes an increase (decrease) in demand for the security by index and pension funds that hold the S\&P 500, which results in an increase (decrease) in price. ${ }^{62}$

2. Relevance to Manipulation. - The preceding discussion of the relationship between trading and price movements illustrates the dif-ficulty of carrying out a successful manipulation. If trading has no effect on price because of the substitution effect, a successful manipulation is impossible. But even if a relationship exists, a successful manipulation is still unlikely to occur.

Consider price movements related to information effects. Trading will affect prices only if the prospective manipulator can convince others that his trading was informed. Trades in an anonymous market are not likely to have this effect. Even when the probability is high that a trader is informed, there is considerable uncertainty about whether trades will affect price. Recall that nearly half of all block trades occur with no change in price. ${ }^{63}$

But overcoming the problem of appearing informed is not enough. To be successful, the prospective manipulator needs prices to rise after he purchases. The more informed he appears, the more likely prices will rise simultaneously with the purchase and not thereafter. And if a premium must be paid for liquidity reasons, ${ }^{64}$ the price is likely to fall after the purchase. This appears to be precisely what occurs. Evidence on block trades shows that when block trades are associated with price increases, the block transaction price (net of commissions) is above both the previous transaction price and the subsequent closing

${ }^{60}$ See Lawrence Harris \& Eitan Gurel, Price and Volume Effects Associated with Changes in the SEP 500 List: New Evidence for the Existence of Price Pressures, 4I J. FIN. 815, 828 (I986); Lamoureux \& Wansley, supra note 59, at 64-65; Stephen W. Pruitt \& K.C. John Wei, Institutional Ownership and Changes in the $S \& P$ 500, $44 \mathrm{~J}$. FIN. 509, 513 (I989); Andrei Shleifer, Do Demand Curves for Stocks Slope Down?, 4I J. FIN. 579, 588 (I986); Woolridge \& Ghosh, supra note 59 , at 23 .

61 See Lamoureux \& Wansley, supra note 59, at 68.

62 An alternative explanation, however, is that the price change is attributable to an information effect. The increase (decrease) in institutional ownership by index and pension funds may itself increase (decrease) the value of the included (excluded) firms because institutional stockholders may monitor management more actively than other stockholders. See id. at 69 .

${ }^{63}$ See Large Block Transactions, supra note 46 , at $245-46$.

64 See infra p. 518 . 
price. ${ }^{65}$ In other words, the price rises simultaneously with the block trade and subsequently falls. This suggests that an attempted manipulative purchase would generally be unprofitable because the manipulator would anticipate buying at a relatively high price.

Moreover, the prospective manipulator faces significant problems at the time of sale. Specifically, a manipulator who is able to convince market participants that he is informed at the time of purchase must do the opposite at the time of sale. If he cannot, he would realize losses even if he were able to sell at the market price. If the sale price were below the market price, as the evidence on block sales implies it would be ${ }^{66}$ his losses would be even greater. The law need not worry about such sure-to-lose strategies.

Liquidity costs further diminish the prospects for successful manipulation. To be successful, the manipulator must be able to sell any shares purchased for more than the price paid. In the example of a stock with a bid-ask spread of $\$ 9-\$ 10$, a prospective manipulator would expect to purchase at the ask price (\$10) and sell at the bid price (\$9) for a loss of $\$ \mathrm{I}$. This liquidity cost is a transactions cost that makes a successful manipulation less likely. We need not worry about a scheme to purchase at $\$ 10$ and sell at $\$ 9$. Unless the prospective manipulator can buy at $\$ 10$ and sell for more than this amount, the scheme is completely self-deterring.

It is frequently asserted that thinly traded stocks are more prone to manipulation than are actively traded securities, perhaps because information and price pressure effects on stock prices may be accentuated in this case. However, liquidity costs are likely to offset these effects. With all else equal, the less actively traded a security, the larger the bid-ask spread. ${ }^{67}$ And the larger the bid-ask spread, the greater the transactions costs that impede a successful manipulation.

Finally, price pressure effects do not appear to increase the probability of a successful manipulation. To the extent that the evidence supports the existence of a price pressure effect, it indicates that securities have supply and demand elasticities no smaller in magnitude than ${ }^{6}{ }^{68}$ This means that a prospective manipulator must purchase

65 See Large Block Transactions, supra note 46 , at $249-52$.

tof See id. at $249-54,264$

${ }^{17}$ See, e.g., Harold Demsetz, The Cost of Transucting, 82 Q.J. E.CoN. 33, 4 I (1968); Hans R. Stoll, The Supply of Dealer Services in Securities Markets, 33 J. Fin. I I33 (1978); Jeha M. Tinic \& Richard R. West, Competition and the Pricing of Dealer Services in the Over-theCounter Stock Market, 7 J. Fin. Quantitative Analysis I 708, I72I (1972).

68 See, e.g., Large Block Transactions, supra note 46 , at 264 (reporting a mean permanent stock price decline of $0.34 \%$ for a sample of block sales averaging $1.63 \%$ of equity); Scholes, supra note $4 \mathrm{I}$, at $193-94$ (finding that in secondary distributions in which "the mean percentage of the firm traded was $2 \%$ and the mean price effect appears to be $2 \%$, the elasticity of demand would appear to be -1 "); Shleifer, supra note 60 , at 580,582 (reporting an average price increase of $2.79 \%$ for S\&P fund purchases thought to average $3 \%$ of outstanding shares). 
at least one percent of the firm's outstanding shares to cause a one percent change in price. Such a large capital outlay exposes the would-be manipulator to tremendous risk because the resulting price increase (of, for example, ten cents for a ten-dollar security) may be less than the transactions costs incurred. Even if the price rises by more than the transactions costs incurred, there is no reason to believe that the prospective manipulator will be able to sell for more than he paid. Price pressure effects are symmetrical. If purchases increase the demand and thus the price, sales will have the opposite effect. Again, the scheme is completely self-deterring.

\section{B. The Difficulty of Identifying Manipulative Trades}

In addition to being self-deterring, manipulative trades are extremely difficult, perhaps impossible, to identify. This difficulty stems from one simple fact - it is hard to read people's minds. For this reason, the law typically requires an objectively harmful act before sanctions are levied. Bad intent by itself is not sufficient. Even when intent is an issue, it is typically determined by reference to objective evidence. ${ }^{69}$

To illustrate, suppose that the issue in a criminal case is whether the defendant murdered someone or acted in self-defense. This inquiry will be undertaken only when someone is dead (an objectively bad outcome). And the investigation of the killer's state of mind to determine whether he acted in self-defense also will focus on objective evidence (whether he reasonably believed he was in danger). ${ }^{70}$

Allegedly manipulative trades present a far different situation. First, there is no objectively harmful act or bad outcome. Only the trades are observable, and they are indistinguishable from all other trades. Moreover, inquiry into the state of mind of the trader is futile because the objective acts taken by the allegedly manipulative trader typically will be identical to those of the nonmanipulative trader.

The law of manipulation is not completely insensitive to these problems. In fact, the difficulty of reading people's minds and thus the need to infer manipulative intent from actions are explicitly recognized as a problem in the area. ${ }^{71}$ The difficulty, however, is that the objective conduct deemed to indicate manipulation is at least as consistent, if not more consistent, with normal market activity.

\footnotetext{
${ }^{69}$ See, e.g., In re The Federal Corp., 25 S.E.C. 227,230 (1947).

${ }^{70}$ See, e.g., Cal. Penal Code $\$$ I 98 (West I988) ("[T]he circumstances must be sufficient to excite the fears of a reasonable person....").

${ }^{71}$ See, e.g, The Federal Corp., 25 S.E.C. at 230 (noting that, "Is]ince it is impossible to probe into the depths of a man's mind, it is necessary in the usual case . . that the finding of manipulative purpose be based on inferences drawn from circumstantial evidence").
} 
Three types of conduct illustrate the practices commonly identified as indicative of manipulative trading: ${ }^{72}$ trading at the end of the day $7^{73}$ short sales; ${ }^{74}$ and making bids at successively higher prices. ${ }^{75}$ In fact, none of these types of trades demonstrates the existence of manipulative intent.

I. Trading at the End of the Day. - Trading at the end of the day is often alleged to be strong evidence of manipulation, perhaps because such trades are thought to be more likely to affect the closing price. Yet studies have established that trading in organized securities markets is heaviest in the period just before the market closes (as well as when it opens). ${ }^{76}$ Trading at the end of the day is common because market participants monitor developments during the day before taking a position prior to the close of trading. Because legitimate trading is concentrated at the end of the day, it is wrong to interpret trading at the end of the day as evidence of manipulation.

Moreover, it is possible that trading at the end of the day is less likely to be manipulative than trading at other times of the day. Recall that a successful manipulation requires both that trading affect price and that the trader be able to sell for more than he paid. Trading at the end of the day could make it less likely that either condition will be satisfied. Because trading is concentrated at the end of the day, any trade at this time is likely to have less informational content than a trade at another time. Thus, any individual trade has a higher probability of affecting price if made at a time other than the opening or closing of trading. The trader who buys at the end of the day also bears more risk because he must hold his shares until the next day. The longer holding period increases the possibility of adverse price movements in the interim.

Trading at the end of the day is most likely to be manipulative when the trading is designed to trigger contractual rights or benefits linked to the closing price on a particular day. But even this situation is ambiguous because legitimate trading is also concentrated during this time. Moreover, as discussed above, it is harder to affect price by trading at the end of the day than during other times. ${ }^{77}$

\footnotetext{
i2 For a general summary of various types of manipulative practices, see Manipulative Practices, supra note 16 , at 99-195.

7 See, e.g., United States v. GAF Corp., 928 F.2d I253, 1256 (2d Cir. I99I).

it See, e.g., I7 C.F.R. \$240.10a-I (1991). The prevalent view that short selling is a form of manipulation is discussed in Restrictions on Short Sales, supra note 17 , at 799-805.

is See Manipulative Practices, supra note I6, at i13-15

it See Lawrence Harris, A Transaction Data Study of Weekly and Intradaily Pattems in Stock Returns, I6 J. FIN. ECON. 99, I I 2 (I986).

is There is, however, one situation in which trading at the end of the day is more likely to affect price. If the very last trade of the day is a purchase, it might cause the closing price to
} 
2. Short Sales. - Short sales are also thought to be indicative of manipulation and are heavily regulated as a result. ${ }^{78}$ Again, however, the premise that short sales reflect manipulative trading is extremely suspect.

Selling short allows those who believe that the price of a security will fall to act upon their "negative beliefs." If selling short were prohibited, the ability of traders to express negative beliefs would be limited by the number of shares currently owned. The claim that short sales are evidence of manipulation requires an ability to distinguish between traders with negative beliefs and those with manipulative inter.t. Because both classes of traders will act identically, however, making this distinction is an extremely difficult task.

Moreover, an attempted manipulation by selling short is at least as self-deterring as any other type of manipulative scheme. Like any manipulative trader, the short seller must bear the costs created by the bid-ask spread and convince other market participants that his trading is informed. He must also hope that prices will fall after he sells and will not rise again simultaneously with his subsequent purchases. If anything, a short seller faces greater costs than other prospective manipulators because he must post margin to cover his position and thus bear the risk that the stock price will rise and force him to cover at a loss.

3. Successive Bids at Higher Prices. - This strategy seems the least likely to result in a successful manipulation. Here the prospective manipulator overcomes the difficulty of causing price increases by offering to purchase at more than the market price. By doing so, however, the manipulator increases the probability of loss and, hence, the self-deterring nature of the scheme.

The prospective manipulator needs prices to rise after he purchases to have a chance of selling at a profit. By purchasing at above the market price to cause a price increase, the prospective manipulator decreases the likelihood that he will be able to sell at a profit. In addition, the prospective manipulator still has the problem of what to do at the time of sale. If his sales cause prices to fall, the chance of loss is greater still.

If successive higher bids are not motivated by manipulative intent, why do they occur? A plausible explanation is that the price is rising for other reasons at the same time the purchases are occurring. Thus, as is the case for trades generally, it is extremely difficult to discern the intent of a trader with objective evidence because manipulative trades are indistinguishable from nonmanipulative trades.

be at the ask rather than the bid. Thus, the last trade of the day could affect price by the size of the bid-ask spread.

is See, e.g., IT C.F.R. \$240. IOa-I (I99I). 


\section{The Social Costs of Prohibiting Manipulation}

Legal rules prohibiting manipulation are costly in several respects. Enforcement costs, for example, are higher for manipulation than for other intentional torts. In the typical case, enforcement costs are incurred only when an injury occurs. By contrast, manipulation depends entirely on the state of mind of the trader. The observable acts are indistinguishable from nonmanipulative trading. As a result, enforcement costs in the case of manipulation cannot be limited to instances of observable injury.

A second type of social cost created by the legal prohibition of manipulation is opportunity cost - the cost of the beneficial activity foregone. This is most obvious in the regulation of short-selling. Current regulation allows short sales only if the most recent price change was an increase. ${ }^{79}$ This prohibition of short sales on downticks results in the elimination of legitimate short sales that would otherwise occur whenever those who did not currently hold a particular security received adverse information about the security. The result is to decrease the speed at which information is reflected in market prices and thus to reduce the efficiency of markets. ${ }^{80}$

Similarly, current regulation prohibits short sales in advance of public offerings. ${ }^{81}$ The stated rationale is that short sellers might otherwise drive down the price of the security prior to the offering and then profit by covering at artificially low prices in the offering itself. ${ }^{82}$ For reasons discussed above ${ }^{83}$ however, there is no reason to believe that this type of trade-based manipulation is likely to succeed. Thus, the regulation provides no benefit. On the other hand, the regulation imposes costs because it prevents those with negative beliefs, perhaps created by the existence of the offering itself, from acting on them by trading.

Even in the absence of a specific regulation, other beneficial activity will be foregone because of the general prohibition of manipulation. The difficulty of distinguishing manipulative from nonmanipulative

79 See Restrictions on Short Sales, supra note 17 , at $805-06$. For a discussion and critique of this regulation, known as the uptick rule, see $i d$. at $799-808,822-35$.

${ }^{80}$ See Douglas W. Diamond \& Robert E. Verrecchia, Constraints on Short-Selling and Asset Price Adjustment to Private Information, I8 J. FIN. ECON. 277, 302-06 (1987).

81 See I 7 C.F.R. $\$ 240$. 10b-2I(T) (prohibiting a short seller from covering a short sale of equity securities of the same class as securities to be offered publicly with securities "purchased from an underwriter or broker or dealer participating in the offering" if the short sale was made after the filing of the registration statement). In adopting this rule in 1988 , the Securities and Exchange Commission identified the prevention of manipulation as its primary objective. See Short Sales in Connection with a Public Offering, Securities Act Release No. 6798, Exchange Act Release No. 26,028, [1988-89 Transfer Binder] Fed. Sec. L. Rep. (CCH) I 84,315 (Aug. $25,1988)$

82 See id.

${ }^{83}$ See supra pp. 51?-19. 
trading means that error costs will be high. Because the sanctions for engaging in manipulation are severe and include criminal penalties as well as the possibility of a lifetime ban from the securities industry, traders, particularly high profile traders such as takeover arbitrageurs, will avoid conduct that might be characterized as manipulative.

Even a seemingly narrow legal rule focusing on "clear" evidence of manipulative intent (assuming such "clear" evidence exists) is unlikely to provide net social benefits. Any rule that addresses the difficult problem of identifying manipulative conduct risks overdeterrence - causing society to bear the costs of foregone beneficial activity. But a rule sufficiently narrow to avoid overdeterrence is unlikely to provide deterrence at all. Moreover, conduct that might be proscribed by a narrow rule is not worth worrying about because such conduct is self-deterring.

\section{Alleged Manipulative Schemes Involving FACTORS OTHER THAN TRADING}

Thus far we have focused on one type of manipulative trading scheme: purchasing to cause prices to rise and then selling at high prices before the price falls again. These schemes can be described as "trade-based manipulations" because the trader's profit results directly from the trades. Trade-based manipulations, however, are not the only possible type of manipulative scheme. In this section, we consider two other possible types of manipulative schemes.

\section{A. Contract-Based Manipulations}

Contract-based manipulations are schemes in which the trader's profit results from his ability to trigger a contractual right or benefit by trading. An example would be purchases by a corporate officer that raise the price of his firm's shares by an amount sufficient to trigger a bonus clause in his compensation package based on the firm's stock price.

One can argue that contract-based manipulations are more properly the subject of legal concern. Such schemes are not clearly self-deterring because the gains from triggering the contractual right could outweigh the losses incurred by the alleged manipulator at the time of sale. Moreover, a legal prohibition of contract-based manipulations can be understood as government enforcement of an implicit term in private contracts. An analogy exists to the moral hazard problem present in insurance contracts. Fire insurance policies, for example, do not cover arson by the insured because of the obvious moral hazard insurance coverage would create. Allowing the corporate manager in the above example to trigger his bonus by trading could create a similar moral hazard. Moreover, because trading in anonymous securities markets is hard to detect, the firm may be unable to monitor the moral hazard. Thus, government regulation 
may be desirable to enforce the implicit term of the compensation agreement. ${ }^{84}$

But it is far from clear that courts should read such an implicit term into the compensation agreement. The firm might not want to prevent all trading by the insider because some trading could have beneficial effects. Suppose the insider purchases because he knows the shares are undervalued, and market participants eventually agree. The insider's purchases, once disclosed or decoded, may be the reason that market participants become more optimistic. In this situation, the insider's purchases are beneficial and his receipt of the bonus after the price has risen is of no concern. The possibility of such beneficial trades, coupled with the difficulty of affecting the price by trading, might make the firm reluctant to limit trades by insiders.

Thus, the fire insurance example is not entirely analogous. Because arson is unquestionably harmful, the insurer wants unconditional deterrence. The same is not true of trading by insiders. Whether such trades are harmful depends solely on the intent of the trader. Trades motivated by a belief that the shares are undervalued are beneficial; identical trades motivated by a desire to move prices in the wrong direction to collect the bonus are harmful. As a result, conditional, not unconditional, deterrence is appropriate. It may be too difficult, however, to distinguish between these two types of trades, ${ }^{85}$ and thus the only options are to allow or prohibit trading altogether. No search for "manipulative" trades would then be necessary.

Moreover, it is incorrect to assume that because trading is difficult to monitor, private parties are unable to reduce the probability of contract-based manipulation. On the contrary, when the possibility of contract-based manipulation is a concern, contracts can be written to deter the practice. Assume that the bonus clause in the above example provided that the insider would get a bonus of $\$ 100,000$ if the stock price of his firm is $\$ 10$ at the close of trading on a given day. Assume further that the security had a bid-ask spread of $\$ 9 / \$$ ro as discussed above. If the last trade is a sale at $\$ 9$, the insider might be tempted to purchase a small quantity at $\$ 10$ on the last trade of the day to collect the bonus. A firm concerned about this possibility, however, has many alternatives. For example, the firm could write a contract under which the bonus would be paid only if the stock closed at \$10 and remained above $\$$ io for some given period of time.

${ }^{84}$ The argument is similar to the defense of governmental regulation of insider trading. See Frank H. Easterbrook, Insider Trading, Secret Agents, Evidentiary Privileges, and the Production of Information, 198 I SUP. CT. REV. 309, 330-38. For a response to this argument, see Carlton \& Fischel, supra note 22 , at $873-75$ (arguing that prohibiting insider trading may not be an efficient way to address moral hazard).

85 See supra Part IV.B. 
If the \$10 price is solely a product of the bid-ask spread, the price will not stay at this level but will fluctuate between this price and $\$ 9$. Such a contract would effectively deter the trade-based manipulative scheme.

That contracts can be written to deter trade-based manipulation does not, however, definitively resolve the question whether a legal prohibition is desirable. First, it is possible that the contract adaptation chosen to deal with the problem of contract-based manipulation is inefficient for other reasons. Lengthening the time the stock price must be above $\$ 10$ in the above example may force the insider to bear too much risk that the price may fall for exogenous reasons. This inefficient contract adaptation might be avoided with a legal rule prohibiting contract-based manipulations. Second, no matter how the contract is written (provided that the bonus is linked to stock price), some possibility exists that the price in the absence of trades might be close enough to the trigger price to make a trade-based manipulation worthwhile. Thus, there may be some benefit, even if trivial, to a legal prohibition of manipulation.

These arguments, however, are weak. The contractual adaptations described above establish that private parties can minimize the risk of manipulative behavior, albeit not perfectly, in the absence of a legal rule. Moreover, the difficulty of negotiating, writing, and enforcing perfect contracts does not establish the desirability of a legal prohibition. The costs of such a prohibition must also be considered. The law, for example, does not regulate the length of time corporate managers take for lunch. The costs of doing so would be prohibitive. Similarly, the costs of a legal prohibition on manipulation, as we have emphasized, ${ }^{86}$ are also high. The difficulty of identifying manipulative trades makes it unlikely that a legal prohibition of manipulation will produce net benefits. ${ }^{87}$

\section{B. Trading Combined with Disclosure}

Cases in which traders atteinpt to profit by combining trading with disclosure might also be thought to pose difficulties for the view that legal restrictions on manipulation should be abandoned. Recall that one of the problems faced by the prospective manipulator is that, if price rises simultaneously with purchase, no possibility of profit exists. The prospective manipulator needs both price to rise after he purchases and then to be able to sell without depressing price. This is extremely difficult to accomplish in pure trade-based manipulative schemes. It is easier to accomplish, however, when trading is combined with disclosure. Consider the case of an investment analyst

${ }^{86}$ See supra Part IV.C.

${ }^{87}$ See infra Part VI. 
with a reputation for identifying undervalued securities. Assume that the analyst purchases shares and then makes a favorable recommendation to clients even though he privately believes that there is no basis for his recommendation. Because of his reputation, the recommendation causes the share price to rise. The analyst then quietly profits by selling at the higher price.

Although such a scheme is not implausible, it is better understood as a fraud than as a manipulation. The harm to other market participants results from a false statement. The trades are relevant only in that they provide the motive for such false disclosure. ${ }^{88}$ The concept of manipulation adds nothing to the inquiry.

If the hypothetical is altered by changing the disclosure from a recommendation to clients to a statement of accumulation, it becomes more difficult. If the statement of accumulation has the same price effect as the recommendation, the possibility for profit is unaffected. The increased difficulty occurs because the disclosure of accumulation is literally accurate. Whether this disclosure should be actionable under the law of fraud is a complicated question. If the statement is equivalent to saying "I think the shares are undervalued and I have no plans to sell," it could be characterized as misleading. On the other hand, because the statement of accumulation is literally accurate, it may be unfair to characterize it as a statement of future intention.

The question whether a disclosure of accumulation, without more, can ever be challenged as false thus presents difficult issues. The problem is most likely to arise in the context of mergers and acquisitions because of the magnitude of price movements that can occur when takeover rumors abound. The law has dealt with this problem by requiring any person holding more than five percent of a company's stock to disclose his future intentions and to update the disclosure when his intentions change. ${ }^{89}$ This requirement extends the scope of the prohibition of fraud by making it impossible to disclose accumulations without also accurately disclosing future intentions. ${ }^{90}$ Thus, the question whether a disclosure of accumulation can ever be actionable is merely a debate over the scope of the prohibition of fraud once again, the concept of manipulation adds nothing to the inquiry.

\footnotetext{
Indeed, existing case law treats this as a species of fraud rather than manipulation. See, e.g., Zweig v. Hearst Corp., 521 F.2d I 29 , I I3I (9th Cir. I975) (assuming without deciding that writing an article praising a company's stock when the author had previously purchased that stock is evidence of a securities fraud violation under Rule rob-5)

nis See 15 U.S.C. $\$ 78 \mathrm{~m}(\mathrm{~d})(1988)$.

(n) This disclosure requirement imposes costs of its own by weakening prospective acquirers property rights in information. See Daniel R. Fischel, Efficient Capital Market Theory, the Market for Corporate Control, and the Regulation of Cash Tender Offers, 57 TEx. L. REV. I, $13^{-1}+(1978)$. Outside the mergers area, the application of anti-fraud laws to trading after disclosure is unclear.
} 


\section{Three Recent Cases of Alleged Manipulation}

We now consider three recent cases involving allegations of manipulation: United States v. GAF Corp., ${ }^{91}$ the Wickes transaction in United States $v$. Milken, ${ }^{92}$ and United States $v$. Mulheren. ${ }^{93}$ Two of these cases (GAF and Mulheren) resulted in criminal convictions that were reversed on appeal. ${ }^{94}$ These mixed outcomes are not surprising in light of the ambiguous nature of the objective evidence regarding allegations of manipulation. The third case (Milken) was litigated in an evidentiary hearing prior to Milken's sentencing; ${ }^{95}$ it also illustrates the difficulty of identifying manipulative trades.

\section{$A$. United States v. GAF Corp.}

GAF Corporation, its vice-chairman (James T. Sherwin), and certain subsidiaries were indicted on multiple felony counts relating to false entries in books and records, improper margin loans, and manipulation. ${ }^{96}$ There were three trials: the first resulted in a mistrial because of a prosecutorial trial error, the second ended in a hung jury, and the third resulted in convictions on all counts. ${ }^{97}$ The Second Circuit reversed the convictions and remanded the case for a new trial. ${ }^{98}$ At that point, the United States decided not to seek a new trial and dropped all charges. ${ }^{99}$

The case arose from the following series of events. In October and November, I986, GAF Corporation wanted to sell a large block of Union Carbide Corporation's outstanding stock and was actively soliciting bids from investment banking firms. ${ }^{100}$ On October 29, Sherwin allegedly asked employees of Jeffries \& Co., a registered broker-dealer, to arrange for the price of Union Carbide, which had

${ }^{91} 928$ F.2d 1253 (2d Cir. 199I).

92759 F. Supp. 109 (S.D.N.Y. 1990).

${ }_{93} 928$ F.2d 364 (2d Cir. I99r). Our analysis of these cases is for academic purposes only: We express no opinion on what the parties actually sought to accomplish in these cases or on the guill or innocence of any party under existing law.

${ }^{9+}$ See GAF, 928 F.2d at $1263 ;$ Mulheren, 9.38 F.2d at 372 .

95 See Milken, 759 F. Supp. at 122-23. Milken had pleaded guilty on unrelated matters. See id. at 110.

96 See GAF, 928 F.2d at 1255,1257 n.2.

97 See $i d$. at 1257 . The $G A F$ case and its various outcomes were widely reported and discussed by commentators. See, e.g., Manipulative Practices, supra note 16, at I 13, 172-73. The facts and circumstances discussed herein come from this source as well as the indictment. See Indictment, United States v. GAF Corp. (S.D.N.Y. 1988) (No. 88 Cr. 962) (hereinafter GAF Indictment].

98 See $G A F, 928 \mathrm{~F} .2 \mathrm{~d}$ at 126,3 .

${ }_{99}$ See Milo Geyelin \& Arthur S. Hayes, Upjohn Settles Liability Suit over Halcion Sleeping Pill, Wall. ST. J., Aug. 12, 1991, at B2.

100 See GAF, 928 F. 2 d at I 256. 
been trading at prices ranging from $\$ 2 \mathrm{I} \frac{3}{4}$ to $\$ 2 \mathrm{I} \frac{7}{8}$, to close at or above $\$ 22$ on October 29 and October 30, and guaranteed Jeffries \& Co. against loss. ${ }^{101}$ The government alleged that the purpose of the manipulation was to "enrich the corporate defendants by manipulating upward th: price of Union Carbide common stock to attract buyers and to maximize the profits to be earned from the sale of Union Carbide common stock owned by the corporate defendants."102

On October 29, I 986, Jeffries \& Co. bought approximately 60,000 shares of stock near the close of trading on the New York and Pacific stock exchanges. ${ }^{103}$ On October 30 , Jeffries \& Co. bought approximately 40,000 shares near the close of trading on these same exchanges. ${ }^{104}$ Union Carbide closed at $\$ 22$ on both exchanges on October 29. On October 30, Union Carbide closed at $\$ 22 \frac{7}{8}$ on the New York Stock Exchange and $\$ 22 \frac{3}{8}$ on the Pacific Stock Exchange. 105 Jeffries \& Co. sold its shares on November 3 and November 4 at a loss. 106 On November 6 and 7, Jeffries \& Co. purchased an additional 20,500 shares shortly before the close of trading; it sold these shares on November 10-12 without suffering any loss. ${ }^{107}$ GAF Corporation sold five million shares (approximately half of what it owned) in a negotiated transaction on November I0. ${ }^{108}$

These facts illustrate the ambiguous nature of alleged manipulations. The government argued that Jeffries \& Co.'s manipulative intent was obvious because it purchased shares on October 29 and October 30 near the end of the trading day. ${ }^{109}$ But, as noted above, ${ }^{110}$ end-of-the-day trades are common and therefore do not distinguish manipulative trades from nonmanipulative trades. Indeed, the defendants pointed out that Jeffries \& Co.'s purchases on November 6 and 7 , which were not alleged to be part of the manipulative scheme in the government's bill of particulars at the third trial, also occurred at the end of the day. ${ }^{111}$

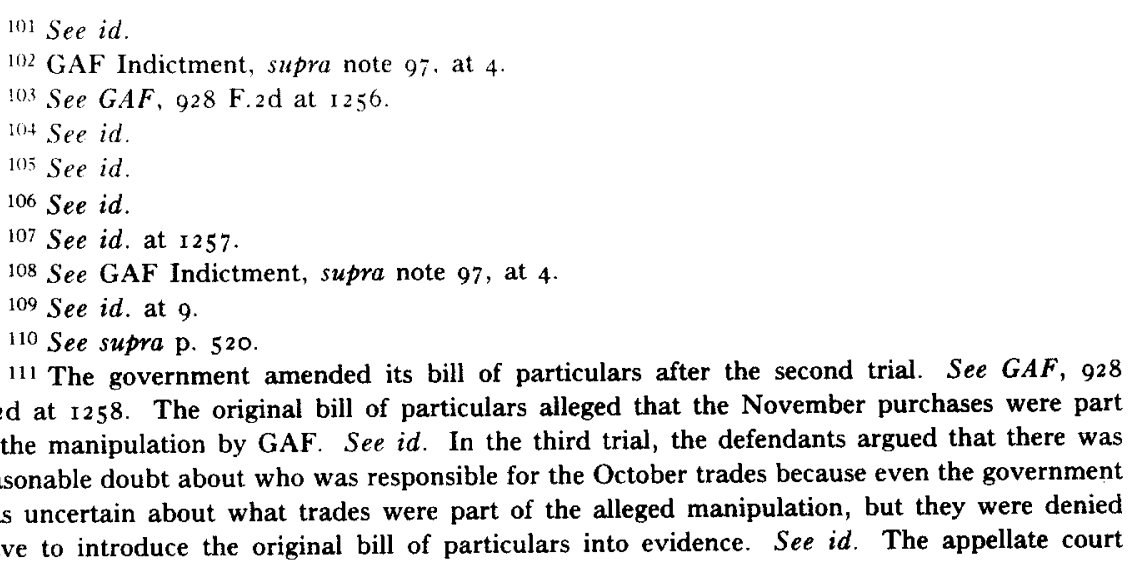


The government further contended that Jeffries \& Co.'s purchases caused the price increases on October 29 and October 30. ${ }^{112}$ But price increases accompanying trades do not establish manipulative intent. Moreover, other explanations for the price increases existed. Price increases are common at the end of the day, ${ }^{113}$ and the relatively small price increases ( $\$ \frac{1}{8}$ on October 29 and $\$ \frac{3}{8}$ on October 30 ) might have been explained by liquidity costs, the bid-ask spread, or other factors such as a rise in the overall market.

The government also argued that the guarantee against loss proved that there was manipulative intent. ${ }^{114}$ But the existence of a guarantee - which was disputed at trial ${ }^{115}$ - proves nothing because such a guarantee might merely have been a means to allow Jeffries \& Co. to trade as GAF's agent. ${ }^{116}$ Moreover, the purpose of the alleged manipulation is unclear. The government claimed that the scheme was designed to increase the profits GAF earned from the sale of Union Carbide common stock. ${ }^{117}$ This explanation is implausible. First, there is no reason to assume that small changes in the price of Union Carbide stock at the end of the day on October 29 and October 30 would have any effect on the sale price of a large block of shares eleven days later. As discussed earlier, ${ }^{118}$ any price increase attributable to trading on October 29 and October 30 would be likely to be temporary unless the trading communicated information about the value of Union Carbide. In addition, parties negotiating a price on November Io would be expected to have considered all past price movements as well as any other relevant information. The closing price on any particular day, let alone a day almost two weeks earlier, would have been of no particular significance. Finally, the shares purchased on October 29 and 30 were sold at a loss on November 3 and 4 , a week prior to the date of the block sale. This sale negated any possibility of profit from the alleged scheme, which suggests that there was never a scheme in the first place.

found that the district court's refusal to admit the initial bill of particulars was an error. See id. at 1263

112 See GAF Indictment, supra note 97 , at 9.

113 See Harris, supra note 76 , at I I I-I 3 , I I 5 .

114 See GAF Indictment, supra note 97 , at 9.

115 See $G A F, 928$ F.2d at $1256-57,1263$.

116 If Jeffries \& Co. was acting as GAF's undisclosed agent, the alleged conduct may have been undesirable, but for reasons having nothing to do with manipulation. At the time of Jeffries \& Co.'s purchases, GAF was prohibited by a standstill agreement it had with Union Carbide from purchasing additional shares. Purchases by GAF or Jeffries \& Co. as its agent may have been in violation of the standstill. The alleged failure of Jeffries \& Co. to record the guarantee was charged as a records violation. See GAF Indictment, supra note 97, at 15-16.

117 See id. at 4 .

118 See supra pp. 517-18. 


\section{B. Wickes}

In United States $v$. Milken, ${ }^{119}$ Michael Milken was indicted on multiple felony counts, several relating to the alleged manipulation of Wickes Corporation common stock. These charges were dropped as part of a plea bargain agreement but were litigated in a sentencing hearing. 120

At the relevant time, Wickes had approximately eight million shares of $\$ 2.50$ convertible exchangeable preferred stock outstanding, which it had issued on April 24, I985.121 The indenture for the preferred contained a redemption feature that gave Wickes an option to redeem the preferred stock prior to May 1988, provided that the closing price of Wickes common stock on the American Stock Exchange equalled or exceeded $\$ 6 \frac{1}{8}$ per share (the "threshold price") for at least twenty of thirty consecutive trading days prior to the call for redemption. ${ }^{122}$

As of the close of trading on April 22, 1986, Wickes common stock had closed at or above the threshold price on nineteen of twenty-eight consecutive trading days. ${ }^{123}$ Therefore, a closing price at or above $\$ 6 \frac{1}{8}$ on either April 23 or April 24 would trigger the necessary condition for redemption. Milken, a representative of Wickes's investment banker (Drexel Burnham Lambert), allegedly asked a third party, the Boesky organization, to purchase enough Wickes stock to cause it to close at or above $\$ 6 \frac{1}{8}$ and allegedly guaranteed Boesky against loss. ${ }^{124}$ During the last half hour of trading on the American Stock Exchange on April 23, I986, the Boesky organization purchased 1.9 million shares of Wickes common stock at prices ranging from $\$ 6$ to $\$ 6 \frac{1}{8}$ per share. Wickes common stock closed at the threshold price on April 23. ${ }^{125}$ Wickes called the preferred for redemption on April 29, and the redemption was completed on or about June 2. Drexel received a fee of approximately $\$ 2.3$ million for underwriting the redemption. ${ }^{126}$ Wickes stock price declined after April 23, and Boesky sold his shares at a loss.

These facts demonstrate that alleged contract-based manipulations, like trade-based manipulations, can also be ambiguous. On one level, the alleged scheme appears plausible. The price movement necessary for the manipulation to succeed was small $\left(\$ \frac{1}{8}\right)$. For this reason, a

119759 F. Supp. 109 (S.D.N.Y. 1990).

${ }^{120}$ See id. at rog.

121 For the facts and circumstances discussed herein, see Indictment, United States v. Milken

(S.D.N.Y. I989) (No. 89 Cr. 4I) [hereinafter Milken Indictment).

122 See id. at $55-56$

12.3 See id. at 56

124 See id

125 See Milken, 759 F. Supp. at 122.

120 See id. 
would-be manipulator willing to commit the necessary capital might reasonably have hoped to cause the price to rise by the desired amount. Moreover, because the desired upward price movement was small, the manipulator might have reasonably expected to be able to sell his shares at about what he paid for them. Therefore, expected trading losses were small. Because the purpose of the manipulation was to benefit from the contractual redemption provision, not from the trading itself, such trading losses might not have deterred this conduct.

But an alternative explanation for the trading is also plausible. Milken, Boesky (who was alleged to be Milken's agent), or both might have believed that the stock represented a good investment opportunity. Similarly, they might have believed that the threshold condition for redemption was likely to occur in any event and the price of

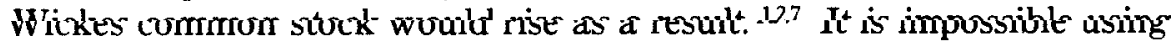
objective evidence to distinguish between the manipulative and nonmanipulative explanations for the trading.

In addition, the trading losses may have been more of a deterrent than it may first appear. Although the expected trading losses may have been small, so too were the expected benefits from the alleged manipulation. The government claimed that the manipulation benefited Drexel because Drexel received underwriting and advisory fees in connection with the redemption of the $\$ 2.50$ preferred stock. ${ }^{128} \mathrm{At}$ the time, however, it seemed likely that Drexel would receive these fees soon in any event. All that was required was a closing stock price above $\$ 6$ on April 23, April 24, or on any nine of the next seventeen trading days (or any twenty of thirty days thereafter). ${ }^{129}$

\footnotetext{
12: Academic studies have found calls of convertible debt to be something of a puzzle for two reasons. First, in contrast to the expected benefit, stock returns are usually negative around the announcement of a call. Second, calls occur significantly later than what is thought to be optimal. These phenomena may be related. See Milton Harris \& Artur Raviv, A Sequential Signalling Model of Convertible Debt Call Policy, 40 J. FIN. I263, I264 (1985). To our knowledge, no one has studied the stock price consequences of optimally timed convertible calls.

${ }_{128}$ Wickes was not a defendant. However, the government claimed that Wickes, too, benefitted from the manipulation because redemption reduced its obligation to pay dividends. See Milken, 759 F. Supp. at 122 . For the reasons discussed in the text, the expected value of this benefit was likely to have been small. Also, note that the investment banking fees paid to Drexel are an additional expense that Wickes had to pay as a result of the redemption. See Milken Indictment, supra note 121 , at 55-56.

${ }^{129}$ In fact, as it turned out, Wickes common stock price never satisfied the necessary conditions for a call after April 23. But no one could have known this on April 23. As stocks generally have positive expected returns, market participants should have anticipated a continued increase in the price of Wickes common stock. One piece of evidence suggests that market participants believed that redemption was virtually certain. The preferred stock, which prior to March had traded at a substantial premium to its conversion value, traded at or about its conversion value during much of April. For example, on April 15, 1986, the closing price of the preferred was $\$ 37 \frac{3}{4}$; its conversion value was $\$ 38.52$ given the closing price of the common
} 
Thus, the expected benefits of early redemption were likely to be low. It is not clear that these expected gains would have outweighed the expected trading costs. ${ }^{130}$

\section{United States v. Mulheren}

In United States v. Mulheren, ${ }^{131}$ defendant John A. Mulheren, $\mathrm{Jr}$., the chief trader and general partner of Jamie Securities Co. ( Jamie), was indicted on the charges that he "conspired to and did manipulate the price of "Gulf \& Western Industries, Inc. (G \& W) common stock. ${ }^{132}$ Mulheren was convicted at trial, but the conviction was reversed on appeal. ${ }^{133}$

In I 985, arbitrageur Ivan Boesky's companies purchased approximately 3.4 million shares of $\mathrm{G} \& \mathrm{~W}$, which represented approximately $4.9 \%$ of the outstanding shares. ${ }^{134}$ In September and October 1985, Boesky had discussions with Martin Davis, G \& W's chairman, in which he proposed taking control of the company, increasing his position in the company, or selling his shares back to the company at $\$ 45$ per share. ${ }^{135}$ These conversations were private, but the press speculated about the possibility of a takeover of $\mathrm{G} \mathrm{\&} \mathrm{W}$ and about the size of the positions held by Boesky and Carl Ichan (another arbitrageur). ${ }^{136}$

After the close of trading on October I6, I985, Boesky again offered to sell his block of shares at $\$ 45$ per share. ${ }^{137}$ G \& W stock had closed on that day at $\$ 44^{\frac{3}{4}} .138$ Davis told Boesky that the company would buy his shares back, but only at the price at which G \& W stock last traded on the New York Stock Exchange at the time of the transaction. ${ }^{139}$ Davis told Boesky to have his investment

$\left(\$ 6 \frac{1}{4}\right)$ and its conversion ratio (6.16). See WALL ST. J., Apr. I6, 1986, at 60. The proximity of the closing price of the preferred stock and the conversion value suggests that market participants expected voluntary conversion to follow the expected forced call for redemption.

130 The Wickes example also illustrates the ability of market participants to reduce the probability of contract-based manipulations by contract design. The preferred stock indenture was designed to make such manipulations highly unlikely. The threshold provision depended on the price of the stock on any 20 of 30 days. Milken, 759 F. Supp. at 122 . At the time the indenture was written no one would have expected the price of the stock on any one day to matter.

1.319 .38 F.2d 364 (2d Cir. 1991 ).

1.32 See id. at 365 .

13. See id at 372 .

134 See id. at 366.

135 See id.

136 See id.

1.5. See id at 367 .

1.38 See id.

139 See id. 
banker contact G \& W's investment banker to arrange the transaction. 140

Boesky called Mulheren before II:00 a.m. on October $17 .{ }^{141}$ Boesky testified that he told Mulheren that he "liked" G \& W stock but "would not pay more than 45 for it" and "it would be great if it traded at 45."142 Mulheren replied, "I understand."143 Shortly thereafter, Jamie placed an order to purchase 50,000 shares of $G \& W$ stock at the market price. ${ }^{144}$ This order was filled at prices of $\$ 44^{\frac{3}{4}}$ and $\$ 44^{\frac{7}{8}}$ per share. ${ }^{145}$ At I I:O9 a.m., Jamie placed another order to purchase 25,000 shares of $G \& W$ at $\$ 45$ or less. ${ }^{146}$ All 25,000 shares were purchased at $\$ 45$ per share at I I:Io a.m. At I I:I 7 a.m., Boesky (and Ichan) sold his stock back to $\mathrm{G} \& \mathrm{~W}$ at $\$ 45$ per share. ${ }^{147}$ Trading in $\mathrm{G} \& \mathrm{~W}$ stock closed at $\$ 43^{\frac{5}{8}}$; Jamie sold its position at the end of the day at a loss. ${ }^{148}$

The government claimed that Mulheren's sole intent was to affect the price of G\&W stock in order to help Boesky. ${ }^{149}$ The Second Circuit concluded that the government failed to carry its burden of proof, ${ }^{150}$ and found that the meaning of Boesky's cryptic conversation with Mulheren was "at best, ambiguous." 151 It then concluded that the observable characteristics of Jamie's transactions - including their size, their method of execution, and their lack of profitability - were at least as consistent with investment intent as with manipulative intent. ${ }^{152}$

The court's analysis is consistent with our own in two important respects. First, the court's discussion shows that manipulative trades cannot be distinguished from nonmanipulative trades without reference to the intent of the trader. Second, the court's analysis illustrates that the observable characteristics of trades cannot distinguish trades made with bad intent from trades made with good intent. Although the court did not say so explicitly, its analysis calls into question whether actual trades should be prohibited as manipulative. ${ }^{153}$

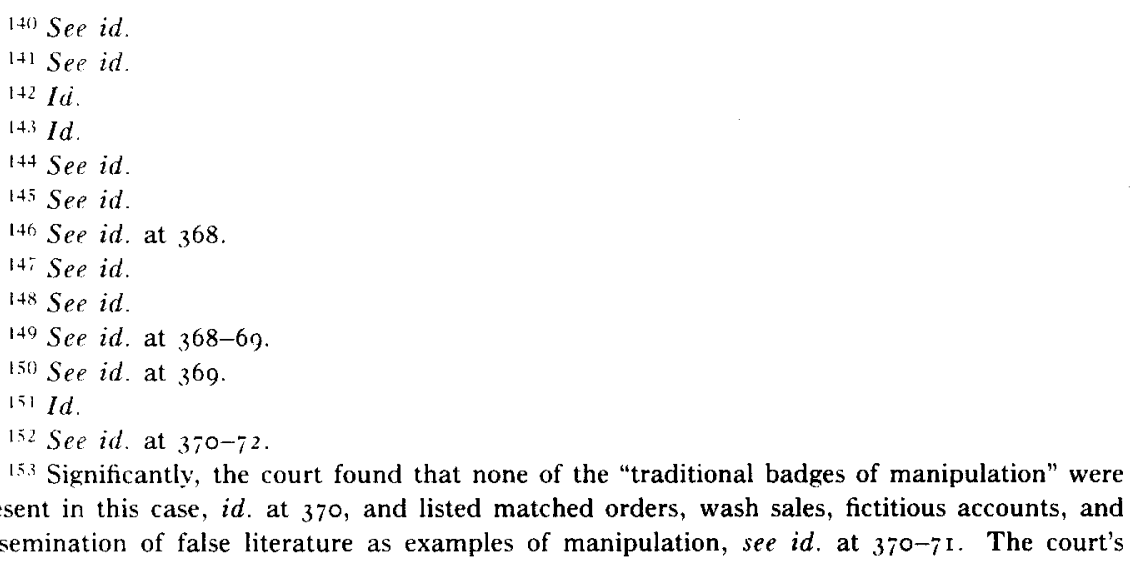


In the final analysis, therefore, the objective evidence leaves the existence of manipulative schemes in GAF, Milken, and Mulheren unclear. In each case, there are alternative explanations for the trading that are at least as plausible as manipulation.

\section{Trading AND "Stabilization" DURing Distributions}

The legislative history of the securities laws, as discussed in the introduction, is replete with extended discussions of the evil "speculative pools." In their simplest form, the pools allegedly involved agreements among issuers, underwriters, and others to raise the price of a security after a public offering by active trading or other means; they would then sell the security at inflated prices to the unsuspecting public before the inevitable price collapse.

\section{A. The Rules and Their Origins}

To deter the pools and other perceived manipulative practices, Congress enacted section $9(\mathrm{a})(2)$ of the 1934 Act, which makes it:

unlawful for any person, directly or indirectly, ... [ [t]o effect, alone or with one or more other persons, a series of transactions in any security registered on a national securities exchange creating actual or apparent active trading in such security or raising or depressing the price of such security, for the purpose of inducing the purchase or sale of such security by others. ${ }^{154}$

While section $9(a)(2)$ focuses on manipulation generally, other provisions deal with particular practices. Section $9(a)(6)$, for example, regulates the practice of "pegging." 155 Unlike the commonly discussed manipulative scheme in which the objective is to buy low, manipulate the price upward, and sell high, pegging is an attempt to maintain a security at a specific price. When undertaken by an underwriter or its affiliates in connection with an initial public offering, pegging is usually referred to as "stabilizing" the offering because it is an attempt to maintain the market price of a security at the offering price. Section 9 (a)(6) does not prohibit pegging or stabilizing per se; rather, it prohibits:

any series of transactions for the purchase and/or sale of any security registered on a national securities exchange for the purpose of pegging, fixing, or stabilizing the price of such security in contravention of such rules and regulations as the [Securities and Exchange] Commission

analysis is consistent with our distinctions between actual and fictitious trades and between manipulation and fraud. See supra Part III.

154 I5 U.S.C. $\$ 78 \mathrm{i}(\mathrm{a})(2)(1988)$.

155 See id. $\$ 78 \mathrm{i}(\mathrm{a})(6)$. 
may prescribe as necessary or appropriate in the public interest or for the protection of investors. ${ }^{156}$

By implication, pegging or stabilizing activity not in contravention of rules promulgated by the Commission is permitted by section $9(a)(6)$.

In I955, the Commission, pursuant to section $9(a)(6)$, adopted rules that for the most part still govern trading during distributions. Rule rob- $6^{157}$ provides, in essence, that it is a manipulative or deceptive practice for any underwriter, issuer, broker, or other participant in the distribution process, either alone or in concert with others, to bid for, purchase, or advise others to purchase any security being distributed until he has completed his part in the distribution. ${ }^{158}$

Thus, the Commission replaced the prohibition of section $9(a)(2)$ with a prohibition of all trading by certain individuals during distributions. The idea was to remedy the vagueness of section $9(a)(2)$, particularly its requirement that an individual not act "for the purpose" of inducing others to trade, and substitute instead an objective definition of specific, prohibited behavior. ${ }^{159}$ Underlying the adoption of Rule rob-6 was the premise that making or inducing purchases during distributions constituted manipulation per se; thus, there was no need for inquiry into purpose or intent.

Rule Iob-6 as adopted contains many exceptions. In particular, the Rule continues the more relaxed regulatory attitude toward stabilizing transactions by including an exception for "[s]tabilizing transactions not in violation of Rule Iob-7."160 Rule Iob-7, in turn, delineates the conditions under which a participant may stabilize an offering of a security. ${ }^{161}$

These rules have turned out to be a nightmare in operation. The original goal may have been to provide simple and objective standards, but the result has been the opposite. Questions such as what type of sale of securities qualifies as a distribution and who is subject to the rule, when, and for how long have proven especially vexing. ${ }^{162}$ Several illustrative interpretative problems have arisen. Must a firm that is involved in some way in the distribution process but is also the sole market maker in the security cease market making - thereby drying up liquidity? Can a firm engaged in a "distribution" by issuing shares in a stock acquisition purchase its own shares in the market

\footnotetext{
$156 / d$.

157 I 7 C.F.R. \$240.10b-6 (1991).

158 See Exchange Act Release No. 5, I94 [1952-56 Transfer Binder] Fed. Sec. L. Rep. (CCH) 1. 76,350 , at 79,458 (July 5, r955) (adopting Rules 10b-6, 7 , and 8 ).

${ }_{159}$ See Nicholas Wolfson, Rule 1ob-6: The Illusory Search for Certainty, 25 STAN. L. REV 809. $810(\mathrm{r} 973)$.

${ }^{160}$ I 7 C.F.R. $\$ 240.10 \mathrm{~b}-6$ (199I).

161 See id. $\$ 240$. Iob- 7 .

162 These problems and others are discussed in Wolfson, supra note 159 , at 815-3I.
} 
prior to the acquisition? Can a firm ever purchase its shares when it has an outstanding issue of convertible securities (and thus arguably a continuing distribution of the common stock)? 163

For our purposes, however, the interesting issue raised by Rules rob-6 and Iob-7 is not the difficulty of implementation, but rather the conceptual justification underlying the rules. The rules presume that trades during distributions are obviously manipulative and that a per se prohibition is therefore appropriate. The rules also assume that there is a distinction between manipulative trades during distributions, which are prohibited, and "stabilizing" trades, which are permitted. Thus, the rules appear to distinguish between "bad" and "good" manipulations. Trades that cause price increases are "bad" manipulations, but trades that prevent price decreases are "good" manipulations. We explore these issues below. First, however, we examine the pools that provided the initial justification for the rules.

\section{B. The Pools Revisited}

Commentators at the time the securities laws were enacted described the practices of the typical pool as follows:

The group first secures an option to purchase at a price higher than the then market quotation a large block of a stock which possesses actual or potential market appeal and an easily controllable floating supply. It is the task of the pool manager and operator to raise the market price above the option price, and, if the supply on the market remains constant, this can be accomplished only by increasing the demand. The most effective manner of inducing others to purchase is to have a favorable ticker tape record which indicates to prospective purchasers that others consider the security to be underpriced. The manager opens a number of accounts with various brokers and, fortified by a knowledge of the condition of the market obtained from the book of a specialist, enters both buying and selling orders with a preponderance of the former so that the price is made to rise slowly upon an increasing volume of transactions. In the cruder form of operation many of these transactions will be washed sales in which the operator is both buyer and seller of the same stock; in others known as matched orders he enters orders to sell with the knowledge that some confederate is concomitantly entering orders to purchase the same amount of stock at the same price. As the price slowly rises, a complex publicity apparatus is set into motion to aid the stimulation of demand. The directors of the corporation whose stock is being manipulated, who may be members of the pool, issue favorable, but not wholly true, statements concerning the corporation's prospects; brokers, likewise interested in the operations, advise customers through market letters and customers' men to purchase the stock; 
subsidized tipster sheets and financial columnists in the daily papers tell glowingly of the corporation's future; "chisellers," "touts," and "wire-pluggers" are employed to disseminate false rumors of increased earnings or impending merger. As the market price passes the option price, the operator exercises his option and, increasing his sales over purchases, carefully unloads upon the public the optioned stock as well as that acquired in the process of marking up the price. ${ }^{164}$

This description is revealing in several respects. First, nothing in the description of the "pool" turns on the existence of a distribution. The same practices could occur in the absence of a distribution. Thus, the description provides no basis for special rules governing distributions. Second, the events described are more accurately characterized as a massive fraud than a manipulation. Phony transactions in the form of wash sales and matched orders are critical to the scheme, as is the dissemination of false information to the public.

So stated, however, it is difficult to understand the furor over the pools. Fraud was already prohibited prior to the enactment of the federal securities laws. If fraud was the concern, there would have been no need to enact section $9(a)(2)$, described as "the very heart of the Act,"165 and to promulgate Rule Iob-6, which prohibit actual trades for the purpose of inducing others to trade even in the absence of fraud. For actual trades, new legislation was necessary to achieve the desired purpose because actual trades, unlike fraud, were not prohibited at common law. Indeed, commentators have argued that it was speculative trading, not fraud, that was perceived to be the primary evil of the pools. ${ }^{166}$

Unfortunately, apart from extensive anecdotal evidence, the pools that so dominated debate in the legislative history of the securities laws have never been studied systematically. It is possible, for example, that contemporary observers mistakenly attributed price declines following the stock market crash of 1929 to the collapse of artificially inflated prices resulting from pools, when the real cause was the economic downturn in the Great Depression. Moreover, there is reason to be skeptical of the simple story told in the legislative history of the securities acts. Stripped of the elements of fraud, pools are a classic trade-based manipulation scheme. As discussed above, such schemes are likely to fail and thus will seldom be undertaken. No reason exists to assume that pools, which are trade-based manip-

\footnotetext{
$16+$ Comment, Market Manipulation and the Securities Exchange Act, 46 YalE L. J. 624, 626-28 (I 9.37) (citations omitted).

16.5 Securities and Exchange Commission, 77 Th Cong., ist Sess., Report of the Securities and Exchange Commission on Proposals for amendments to the Securities Act of 1933 ANd the Securities Exchange ACt of 1934, at 50 (Comm. Print 1941).

16t See Thel, Manipulation Under Section ro(b), supra note 4, at $409 \mathrm{n} .22 \mathrm{I}$ (collecting citations).
} 
ulative schemes in the context of distributions, are more likely to be successful than any other suchi scheme.

\section{Stabilizing Trades}

As noted above, stabilizing trades to prevent price declines are permitted under Rule Iob-7 as long as the possibility of such trades is disclosed to investors. But it is far from obvious that an underwriter or other participant in the distribution process would trade for this purpose. It is not clear that the trading can prevent price declines. In most cases, trading has no effect on prices and thus the scheme is likely to fail. ${ }^{167}$ Moreover, disclosed trading for the purpose of "stabilizing" the price may in fact cause prices to fall when they would not have done so in the absence of the disclosure. Investors who assume a relationship between trading and price will reason that the plan of stabilization has artificially elevated the security's price, and will, as a result, pay less for shares. In other words, the disclosure of the plan to stabilize may act as a signal that the security is overvalued - the opposite of the intended stabilizing effect. The more logical way to stabilize the price would be to announce that none of the participants in the distribution process will engage in stabilizing trades.

This analysis suggests that stabilizing trades, if and when they occur, are explained by something other than an attempt to prop up the price to facilitate the distribution. One alternative is that stabilizing trades are a form of investor insurance provided by underwriters to investors. The aim of the trades under this alternative is not to prevent a drop in prices, but rather to absorb losses if the price of a newly issued security falls below a certain level. A second possibility is that the purchases are designed to offset price pressure effects created by the offering. Still another possibility is that the purchases are designed to communicate the underwriter's private information about the value of the security to market participants and thereby cause them to revise upward their estimate of the security's worth. Under any of these alternatives, disclosure of a plan to stabilize would not have the perverse effect of causing the security's price to fall.

Unfortunately, none of these alternative explanations for stabilizing trades is completely satisfactory. The investor insurance explanation seems inconsistent with the riskiness of initial public offerings, which is one of the common explanations for the underpricing of such offerings. ${ }^{168} I^{f}$ investors are insured against downside risk, they should

167 See supra Part IV.A.

168 See, e.g., Kevin Rock, Why New Issues Are Underpriced, I5 J. FIN. Econ. 187, 188 (I 986) (arguing that the offering firm must price shares at a discount to guarantee that they are purchased by uninformed investors); Ivo Welch, Seasoned Offerings, Imitation Costs and the 
earn lower, not higher, expected returns in initial public offerings. The price pressure explanation also is not entirely convincing. The underwriter could avoid the problem by spacing out the offering over a longer period, although at a cost of bearing increased price risk. Moreover, studies of primary and secondary offerings have concluded that there are no price pressure effects to offset (at least on average), and, as a result, trading for this purpose is unnecessary. ${ }^{169}$

Finally, the information explanation is not persuasive. As long as the trading is anonymous, any signal will be noisy and thus ineffective. Even if the trading is disclosed or otherwise decoded, the signal will be meaningful only if the trades reflect a decision to buy and hold until the private information possessed is revealed. A decision to buy and immediately resell conveys little if any information to market participants because no guarantee exists that the underwriter will bear the loss if it has no private information about the security's value. And because an announcement of an intent to purchase for the purpose of stabilization contains no such guarantee, neither the announcement nor the trades themselves should affect price.

In the final analysis, therefore, stabilizing trades are something of a mystery. Perhaps they never occur or occur rarely for idiosyncratic reasons that include the explanations discussed above. Thus, although the insurance, price pressure, and information theories do not provide a general explanation for trading by participants in the distribution process, it is possible that one or more of these theories might explain trading in a particular distribution. For example, there may be a particular risk-sharing arrangement in some distributions (a form of insurance), or some distributions may have unexpected price pressure effects. Similarly, there may be an understanding in some distributions that the underwriter will buy and hold or otherwise commit to bearing the costs of a buy and hold strategy even if the purchased security is not held. A final possibility is that firms disclose an intent to engage in stabilizing trades in order to trade for some completely unrelated purpose such as investment. Until the practice is studied seriously, however, the purpose of stabilizing trades, as well as the frequency of the practice, will not be fully understood.

\section{EXCESSIVE MARKUPS}

Broker-dealers in over-the-counter markets are sometimes accused of manipulation when they charge retail customers "excessive" markups. ${ }^{170}$ Dealers typically quote both a bid price and an ask price in

\footnotetext{
Underpricing of Initial Public Offerings, $44 \mathrm{~J}$. FiN, 42I, 445 (1989) (describing how firms underprice initial public offerings to obtain a higher price at a seasoned offering).

${ }_{169}^{16}$ See sources cited supra notes 49-50.

170 See Manipulative Practices, supra note $\mathrm{I} 6$, at $128-29$.
} 
the interdealer or wholesale market. The bid price is the price at which a dealer is willing to purchase shares from another dealer; the ask price is the price at which he is willing to sell. A dealer who also acts as a retail broker (sometimes called an "integrated dealer") purchases shares from customers at his bid (or, perhaps, at some markdown from his bid) and sells those shares to his customers at a markup above the current interdealer ask price. If the markup (or markdown) exceeds the prevailing market price by certain parameters, it is deemed excessive.

What markups are excessive? Article III, section 4 of the NASD Rules of Practice require that transactions be executed at a fair price. ${ }^{171}$ The Interpretation of this rule by the Board of Governors establishes a five percent markup from the prevailing market price as a guideline for determining a fair spread. ${ }^{172}$ The SEC considers undisclosed markups (or markdowns) in excess of ten percent of the prevailing market price to be fraudulent. ${ }^{173}$ Such excessive markups are often alleged to be part of a scheme to manipulate the price of a stock. ${ }^{174}$

Nevertheless, the alleged wrong attributable to excessive markups arises from a concern about either fraud or the exercise of monopoly power; calling it manipulation does nothing to advance the analysis. Note first that an excessive markup violates section Io(b) only if the broker-dealer failed to disclose it. ${ }^{175}$ As discussed in Part III, nondisclosure, when there is a duty to disclose, is properly viewed as a form of fraud, not manipulation. To understand the concern about monopoly power, note that the determination of the prevailing market price depends on the characteristics of the interdealer market. When there is an active interdealer market, the "prevailing market price" for purposes of markup calculations is determined by reference to the ask price. In contrast, when a sole market maker "dominates and

1:1 See id. at 129

172 See id.

173 See, e.g., In re Stuart-James Co., Inc., Exchange Act Release No. 26,700, 1989 SEC LEXIS 659, at * (Apr. 5, 1989) (announcing that proceedings had been instituted by the SEC on the grounds that Stuart-James Co., a broker-dealer, violated the securities laws by charging excessive undisclosed markups on the securities of UMB Equities, Inc., and Find SVP, Inc.) In re Altstead, Dempsey \& Co., Exchange Act Release No. 20,825|I984 Transfer Binder| Fed. Sec. L. Rep. (CCH) $8,3,607$, at 86,740 (Apr. 5, I 984 ).

174 See Joseph I. Goldstein, Sarah B. Ackerson \& Laura A. Wovack, Division of Enfercement, SEC, An Overview of Market Manipulation: Legal and Practical Aspects I5 (Nov. 8, I 990) (Virginia Polytechnic Institute and the American Bar Association Conference) (unpublished manuscript on file at the Harvard Law School Library).

1 .5 See id. at 2 I (citing Charles Hughes \& Co. v. SEC, I 39 F.2d 4.34, 4.36-67 (2d Cir. I94.3); and Duker \& Luker. 6 S.E.C. 386, 388-89 (1939)). Goldstein and his coauthors note that nondisclosure is not an essential element in showing a violation of the NASD rules, but disclosurc is one of the factors the NASI considers in determining whether a markup was excessive. See id. 
controls" the market for a particular security, the prevailing market price is determined by reference to the broker-dealer's contemporaneous cost. ${ }^{176}$

To illustrate, suppose that the current interdealer market is \$Io bid and \$I I ask. Without domination and control, a market maker could purchase from a customer at $\$ 9.50$ (a five percent markdown from $\$ 10.00$ ) and sell to another customer at \$II.55 (a five percent markup from $\$ \mathbf{I} I .00)$. However, if a broker "dominates and controls" the market and purchased from one customer at $\$ 9.50$, a price of more than $\$ 9.975$ (a five percent markup from the contemporaneous cost of $\$ 9.50$ ) in a subsequent sale might be considered excessive. The usual rationale for ignoring the wholesale spread in this situation is that the prices other dealers pay the "dominant" dealer are "artificial" because the demand dealer, who "controls" the wholesale price and has lower costs, can charge other dealers whatever it wants. Concern about the ability to set price is what the regulation of monopoly is all about. Calling this concern manipulation adds nothing.

Moreover, concern about the exercise of monopoly power in these circumstances is unfounded. First, the premise that a sole market maker has lower costs has no economic basis. None of the costs generally borne by market makers can be avoided by a sole market maker. In general, market makers bear holding costs (the costs attributable to price changes during the period when a market maker is holding inventory), information costs (costs attributable to trading with informed investors), and the costs of maintaining a presence in the market, searching for customers, and executing transactions. Whenever a sole market maker trades, it necessarily bears these costs. If anything, the costs incurred by a sole market maker may be higher than the costs incurred by multiple market makers (in other stocks) because sole market makers deal in particularly speculative and thinly traded stocks and thus face higher holding and information costs. ${ }^{177}$

Furthermore, there is no necessary relationship between the number of market makers and the existence of market power. A sole market maker's customers are free to transact with other market makers who might decide to make a market in the stock (as well as in any other security). If spreads are excessive, the lure of profits is likely to induce other broker-dealers to enter the market. In addition, even if a sole market maker is able to quote spreads without regard to the quotes of other, competing market makers, it cannot (without fraud) affect the willingness of buyers (sellers) to purchase (sell) at the prices it sets. As a market maker increases its ask price (reduces its

1; See In re Alstead Dempsey \& Co., [1984 Transfer Binder] Fed. Sec. L. Rep. (CCH) If 83,607 , at $86,7,39$.

17 See Stoll, supra note 67 , at I $137-42$, I I $44-46$. 
bid), the quantity that customers are willing to buy (sell) at that price decreases. Furthermore, when choosing which stocks to trade, customers may avoid securities that have large spreads. As discussed in Part IV, when demand (supply) is elastic, suppliers (demanders) of a particular security cannot have market power.

\section{Futures MARKETS}

Special characteristics of futures markets - particularly the expiration of futures contracts - create the possibility of manipulative schemes somewhat different from the manipulative schemes discussed above. Nevertheless, the concept of manipulation serves no useful function in futures markets, either.

\section{A. Manipulation and the Economics of Futures Markets}

A commodity futures contract is a standardized agreement to buy or sell a fixed quantity and grade of a commodity to be delivered at a specified time in the future. There is little concern about manipulation in futures markets prior to the expiration of a futures contract because at other times the market generally is extremely competitive and, therefore, no single trader can affect the futures price. One reason is that the market for the commodity (such as wheat) underlying futures contracts is typically competitive. Moreover, futures contracts are easily traded by both hedgers (those who expect to demand or supply the underlying commodity at expiration) and speculators (professional investors who hope to profit by successfully anticipating price movements) because they have standardized terms and performance guaranteed by a clearing house. Entry and exit are easy because anyone can buy or sell a contract. The presence of professional investors who have access to capital and information also improves the liquidity and efficiency of futures markets.

In addition, there are good substitutes for any particular futures contract. A hedger who wants to sell a commodity can sell today or store his commodity and sell it in the future. Similarly, a speculator who wants to bet on a rise in the price of corn might choose among various futures contracts that mature in different months, for delivery in different locations, or for delivery of different grades of corn. The competitive market for the underlying commodity, the ease of entry and exit, the availability of capital and information, and the existence of close substitutes ensure that in most circumstances futures prices are competitive. ${ }^{178}$

1:8 This is not to say that one should be unconcerned about fictitious trades such as wash sales. As we noted above, however, such trades can be understood as a species of fraud. See supra p. 5 IO. Here, we examine whether real trades ought to be prohibited because of concerns about manipulation. 
These conditions, however, may not hold near the time when a particular futures contract expires. At that time, the deliverable supply of the commodity is fixed (or can be augmented only by transporting additional supply at some cost). The demands of "short" futures traders for supplies of the commodity to satisfy their obligations to "longs" are inelastic. ${ }^{179}$ For shorts, other contracts are a poor substitute because they do not provide the underlying commodity at the right time and in the right place. The absence of substitutes means that market power can be achieved if the ownership of contracts (and the underlying supply of the commodity) becomes sufficiently concentrated relative to the competitive supply of the commodity at expiration. ${ }^{180}$ Such market power can lead to noncompetitive pricing in both the futures market and the spot market for the commodity. 181

The possibility of noncompetitive pricing distinguishes futures markets from other securities markets. A trader who is able to monopolize the supply of, for example, IBM common stock (as implausible as this seems) would not expect to be able to sell small quantities at prices above the competitive market price. Attempts to sell at a higher price would cause potential buyers to turn to other investments that provided a comparable return (depending on the amount of risk) at a lower price. Such easy substitution is not possible when a futures contract expires. Shorts must either satisfy their contractual obligations by purchasing the commodity in the spot market and delivering it to the longs, or get longs to agree to a cash settlement - in effect purchasing the commodity from the longs. If a trader obtains market power through acquisitions of a substantial long position relative to the deliverable supply held by others, shorts will probably have to pay more than the competitive price for the commodity to satisfy their obligations to the long (or pay more than the competitive price for long futures contracts to offset their short position).

\footnotetext{
17 "Shorts" are traders who have agreed to sell the underlying commodity at expiration; "longs" are traders who have agreed to purchase

${ }^{180}$ A "squeeze" is usually defined as a situation in which the open interest of an expiring futures contract exceeds the deliverable supply. A "corner" is defined as a situation in which the open interest of an expiring futures contract exceeds the deliverable supply of a commodity because longs own and withhold part of the deliverable supply from the market. Both situations result in noncompetitive pricing because the longs have market power.

${ }^{181}$ By noncompetitive pricing, we mean prices above those that would result if the ownership of long futures contracts and the underlying spot commodity was unconcentrated. Many commentators refer to high prices that may occur when futures contracts expire as "artificial," because these prices do not reflect "legitimate forces of supply and demand." See Richard D. Friedman, Stalking the Squeeze: Understanding Commodities Market Manipulation, 89 MicH. L. REV. 30, 55 (I 990) (criticizing this approach). As discussed below, high prices will occur when supply is relatively short, demand is relatively high, or a trader obtains market power. Such prices do reflect the existing conditions of supply and demand.
} 
Such market power can arise through intentional conduct. For example, a trader might secretly purchase a large amount of the open futures contracts and deliverable supply of a particular commodity with the hope that, when the contracts expire, he (or they) will have sufficient market power to extract a high price from the shorts either in settlement of their contracts or for the purchase of the underlying commodity needed to satisfy their contractual obligations.

Such market power may also arise, however, without any intention on the part of a trader to obtain it. For example, a bullish trader may purchase a substantial long position because he believes supplies will be tight and prices will rise. If his position turns out to be sufficiently large relative to the deliverable supply, he may find that he has market power at expiration. Supply shocks (such as a poor crop or a fire in a storage depository) or demand shocks (such as unanticipated exports) may also create market power for longs.

\section{B. The Definition of Manipulation in Futures Markets}

The above discussion establishes that market power can arise from legitimate trading activity. Presumably, any long trader wants to make as much money as he can. Of course, a long trader who finds himself with market power, whether or not he obtained it intentionally, will probably take advantage of the opportunity to charge prices above the competitive price. Thus, unlike making a false statement, noncompetitive pricing at expiration is not a bad act that provides an objective test for identifying manipulative trading in futures markets. There is no objective test that distinguishes the manipulative trades from other trades that may or may not lead to the exercise of market power. ${ }^{182}$

As with securities markets, one must examine intent to distinguish manipulative from nonmanipulative conduct in futures markets. Not surprisingly, most commentators stress intent when defining the term "manipulation." Thus, Edwards and Edwards find that the "classic' futures market manipulation(s) . . . all involve commonplace, bona fide, futures trading activities, but activities which are alleged to be undertaken in a manner calculated to produce artificial price effects." 183 Johnson states that "the principal characteristics of a ma-

\footnotetext{
1:2 Perhaps the exercise of market power is, in and of itself, a bad act that ought to be prohibited. This is not completely obvious because the possibility of market power provides incentives for traders who believe prices will rise (because future supply is insufficient) to go long and incentives for shorts to obtain deliverable supplies to alleviate possible shortages. Nevertheless, much of the current regulatory structure attempts to prevent the exercise of market power without regard to its cause. Position limits and the occasional implementation of special rules that require particular traders to reduce their holdings or prevent any traders from increasing their net positions are examples of such regulation.

13. Edwarri: \& Edwards, supra note 19, at 337 (emphasis added).
} 
nipulation are the ability to influence market prices, the intent to do so, and the accomplishment of that purpose to create artificially high or low prices." 184 Professor Friedman considers two alternative definitions of manipulation, both of which require intent to exercise market power. ${ }^{185}$

Definitions that do not include intent fail to distinguish manipulative conduct from legitimate market activity. For example, McDermott defines a squeeze as "a trader's buying or threatening to take delivery of " more than the maximum deliverable supply of a commodity owned by cthers. ${ }^{186}$ Under this definition, a trader who purchased futures contracts and deliverable supplies of a commodity because he wanted to obtain a large quantity of the commodity and, at expiration, found that the shorts were unable to obtain additional deliverable supplies, would be guilty of manipulation. ${ }^{187}$ If he concealed his position (as most buyers would), this conduct might also be considered manipulative under Easterbrook's "reasonable economic definition of manipulation" as "conduct in which the profit flows solely from the trader's ability to conceal his position from other traders and the trades do not move price more quickly in the direction that reflects long-run conditions of supply and demand."188

But concealment does not distinguish manipulative trades from legitimate trades. A trader who is able to predict that supplies will be short and prices will rise would want to purchase a large quantity of a commodity as cheaply as possible. To do so, he will probably conceal his position and intentions from others. This secrecy is necessary for him to profit from his ability to predict future conditions of supply and demand. If the trader did not conceal his position, current futures prices would rise to reflect the information the trader had about future conditions. Recognizing this, Easterbrook distinguishes between "secret strategies necessary to capture the value of new information about underlying conditions and secrecy designed to cause prices to diverge from those that reflect the underlying conditions." 189 This additional distinction requires the same inquiry into intent (wh?t was the strategy designed to accomplish?) required by the usual definitions of manipulation.

${ }^{184}$ Philip M. Johnson, Commodity Market Manipulation, 38 WASH. \& LEE L. REv. 725 , 7.32 ( $198 \mathrm{I}$ ) (some emphasis omitted).

185 See Friedman, supra note 181 , at $35-36,50-51$. The initial approach, which Friedman criticizes as incomplete, defines manipulation as conduct "motivated by the expectation that the conduct itself would affect the market price." Id. at 36 (emphasis omitted). Friedman then proposes a modified approach in which "intent is the central issue." Id. at 58 .

186 McDermott, supra note 2.3, at 204

15: McDermott, of course, recognized that the definition of a squeeze could include transactions that were "innocent and legal." $I d$. at 205 n. 10.

$18 \%$ Easterbrook, supra note $2 \mathrm{I}$, at Si 18.

iso $I d$. 
The search for "artificial prices" also does not distinguish manipulative trades from legitimate trades. What distinguishes an artificial price from a non-artificial price? Commentators and courts have suggested that "unusual" prices are artificial. ${ }^{190}$ Futures prices are "unusual" if they result in unusual futures price differentials between contract months, unusual intermarket spot price differentials (the spread between the spot prices of different grades of the commodity or the spread between spot prices of the same grade in different locations), or unusual intertemporal variation in spot prices. ${ }^{191}$ None of these tests distinguishes artificial prices from non-artificial prices because, whenever unusual conditions of supply or demand occur, such comparisons will demonstrate that prices are "unusual." For example, if the supply of a particular commodity in a particular location is unexpectedly low at expiration but future supplies are expected to return to normal levels, both the futures price differentials and the intermarket cash price differentials will be high. Moreover, because spot prices would first rise as the shortage develops and then fall as it is alleviated, unusual intertemporal price variation will occur. Scarcity will thus result in unusual prices; therefore unusual prices alone cannot distinguish scarcity from noncompetitive prices.

Still, it may be possible to determine when unusual prices have arisen because of the exercise of market power. Therefore, one could define artificial prices as unusual prices that arise from the exercise of market power. ${ }^{192}$ But this definition does not distinguish manipulative trades from nonmanipulative trades because, as discussed above, market power can arise from legitimate trades. If the concern in futures markets is the exercise of market power, the concept of manipulation

\footnotetext{
190 For example, Easterbrook suggests that "[s]omeone searching for manipulation might look for . . . the telltale sign of sudden price fluctuations." Id. Staff economists at the Commodity Futures Trading Commission reportedly rely on "an evaluation of changes in cash and futures price levels, futures price differentials between contract months (spreads), cash and futures price differentials (basis), and intermarket cash price differentials, particularly between delivery points and other locations." Staff of Senate Comm. on Agriculture, Nutrition, and Forestry, 96Th Cong., 2D Sess., Report of THe Commodity Futures Trading Commission on Recent Developments in the Silver Futures Markets i8-19 (Comm. Print 1980) (hereinafter REPORT OF THE CFTC]. The Cargill case discussed below also relies on unusual price movements. See infra Part VIII.D.

191 Some commentators suggest as well that an unusual spread between the future and the spot price of the commodity is also evidence of price artificiality. See, e.g., Easterbrook, supra note $2 \mathrm{I}$, at Sri 8 . However, because the actual commodity can be used to satisfy the futures contract, the future and spot prices must be closely related near expiration. In other words, if the futures price is artificial, so too is the spot price. Therefore, an unusual spread between the futures and the spot price is more likely to indicate poor price data than anything else.

192 This is the definition used by Edwards \& Edwards. See Edwards \& Edwards, supra note 19 , at 345 (construing "an artificial price to be any price other than one obtained when all cash and futures market participants are price-takers" and defining a manipulator as "one who has and uses monopoly power to effect an artificial cash and/or futures price").
} 
is superfluous. But if the concern in futures markets is trading that creates market power, identifying such trading requires more than the existence of noncompetitive prices at expiration. Again, just as with other securities markets, we are left with no objective definition of manipulation in futures markets.

\section{Are Manipulations in Futures Markets Self-Deterring?}

Successful manipulations appear to be more likely to occur in futures ma kets than in other securities markets. As discussed earlier, successful manipulations require both that trading cause the price of the relevant futures contract to rise and that the manipulator be able to sell at a price higher than his purchase price. A manipulator may be able to satisfy both conditions if he can secretly accumulate enough futures contracts or deliverable supply of the underlying commodity to obtain market power at expiration. Secret purchases would allow the manipulator to buy at a price that did not reflect the coming squeeze at expiration. The squeeze, caused by the exercise of the manipulator's furtively acquired market power, might allow the manipulator to sell at a higher price than that at which he purchased.

But manipulation in futures markets is not easy. One reason is that the acquisition of market power requires a large amount of capital. A would-be manipulator needs to purchase a sufficient quantity of contracts and, perhaps, stocks of the underlying commodity to obtain market power. For some commodities, such as Treasury securities, this is likely to be impossible. ${ }^{193}$ For other commodities, extensive capital is necessary to finance current margin requirements and commodity purchases, and subsequent capital is needed to provide for margin calls and to finance purchases at expiration.

There are also problems at expiration. To cause a price increase at expiration, the manipulator, like any monopolist, must withhold supplies of the commodity; if he provides the competitive supply, he will receive only the competitive price. By keeping supplies off the market, the manipulator may be able to obtain a high price on sales of futures contracts or the underlying commodity to the shorts - but what does he do with his remaining stocks of the unsold commodity?

Even if the manipulator continues to withhold supply, he is unlikely to receive as high a price. Withholding supply causes prices to rise at expiration because the shorts have inelastic demands; they must fulfill their contractual obligations. After expiration, demand is likely

${ }^{14.3}$ Commodities that are readily available and can be easily transported cannot be cornered. See Easterbrook, supra note $2 \mathrm{I}$, at $\mathrm{S}_{\mathrm{I}}{ }_{9}-\mathrm{IO}$. Commodity contracts that allow for cash settlement when the settlement price is determined in a reference market much larger than the futures market, such as stock index futures, are also poor candidates for manipulation. See id. at Si ro; Edwards \& Edwards, supra note I9, at 359-60. 
to be far more elastic. Other grades of the commodity or related commodities that could not be used to satisfy delivery requirements under the terms of the futures contract may be good substitutes for the underlying commodity in other uses. In addition, unlike the shorts, other potential buyers of the commodity are not contractually required to purchase at expiration; they may be able to substitute intertemporally. Thus, the ability to obtain a high price at expiration does not necessarily imply the ability to obtain a high price after expiration. And additional sales by the manipulator are likely to push the price down even farther.

Moreover, although a would-be manipulator in futures markets may be confident that his position will cause prices to be higher at expiration than would otherwise be the case (because of the inelastic demand at expiration), he has no assurance that the price at expiration will yield him a profit. An unexpected increase in deliverable supplies or a reduction in demand could cause prices to be lower than anticipated. Even if such conditions do not occur at expiration, they may occur before the manipulator has been able to unwind his position after expiration.

For these reasons, attempted manipulations in futures markets are extremely risky. In what is perhaps the best known recent alleged manipulation, the Hunt family took substantial long positions in the silver futures market and accepted large quantities of silver in EFP (exchange futures for physical) transactions between September I 979 and March I980. ${ }^{194}$ Allegedly as a result, the spot and futures prices of silver rose substantially through mid-January $1980 .{ }^{195}$ Prices remained high through March 1980 but then began to fall as silver stocks increased. ${ }^{196}$ These price declines resulted in margin calls that the Hunts were unable to meet. ${ }^{197}$ Sales by the Hunts' brokers to meet these margin calls caused additional price declines, ${ }^{198}$ and the Hunts reportedly lost more than a billion dollars. ${ }^{199}$ Legal rules are unnecessary to deter such outcomes.

Another reason that legal prohibitions are unnecessary is that futures exchanges have incentives to adopt trading rules and contract terms that reduce the costs associated with the exercise of monopoly

194 See Seventeenth Report by the Comm. on Gov't Operations, Silver Prices and the Adequacy of Federal ACtions in the Marketplace. 1979-80, H. R. Doc. No. 395 , 97th Cong., ist Sess. 40-4I (I981) [hereinafter Silver Prices].

19.5 See id. At least part of the silver price increase has been attributed to exogenous factors such as a general increase in the price of precious metals. See, e.g. REPORT OF THE CFTC. supra note 190 , at 40 .

196 See Silver PRICES, supra note 194, at 8, 36.

197 See REPORT OF THE CFTC, supra note 190. at 83.

198 See id. at 46,92

199 See Easterbrook, supra note 21, at Siro n.5. 
power that may result from corners and squeezes. Recall that the terms of futures contracts are determined by the organized exchanges on which futures trade. To survive, these exchanges must attract business, compete with other exchanges, and compete with other securities markets. This competition ensures that exchanges will adopt contract terms and trading rules that reduce the costs of manipulations. ${ }^{200}$ There are several examples of such rules: position limits, daily price limits, and special rules that require divestitures, prohibit position increases, or change the terms of delivery to enlarge the deliverable supply.

However, rules designed to prevent the exercise of market power also have costs. First, such rules reduce the utility of the futures contract as a hedge. Large positions cannot be hedged when there are low position limits; large price swings cannot be insured against when there are small price limits; and a concern about obtaining supplies in one place (Chicago, for example) will not be alleviated if the exchange allows delivery in another (Kansas City). Moreover, rules designed to prevent the exercise of market power also reduce the return to information about future prices and thus reduce the incentive for market participants to gather such information. A trader who must spend $\$$ I0, 000 to learn whether contract prices will rise $\$ \mathrm{I}$ would be unwilling to do so if he is allowed to buy only 3,000 contracts. Similarly, such rules may reduce the efficiency of futures markets - a trader who is unable to act on his information is unable to communicate information to other market participants through his trades. Such rules, therefore, make future prices a poorer signal of future spot prices than might otherwise be the case. Because rules preventing the exercise of market power have costs as well as benefits, optimal rules might not seek to prevent all exercises of market power.

\footnotetext{
200 This does not mean that exchanges necessarily will adopt the optimal amount of precautions. Exchanges will continue to take additional precautions until the marginal private gains equal the marginal private costs. This level of precaution will be optimal only if the private gains and costs approximate the social gains and costs. But this is likely to be the case because traders on the futures markets are those who bear most of the costs and receive most of the gains from trading in these markets. See Easterbrook, supra note $2 \mathbf{1}$, at $\mathrm{SI}_{1} 3$.

Some commentators have claimed that exchanges will not take the optimal amount of precautions because exchanges do not take into account the interests of those who are affected by futures prices but do not participate in the futures market. See, e.g., id. at Srr2-r3. An example is a farmer who looks at futures prices to determine how much to plant, but does not hedge his crop in the futures market. It is not obvious, however, that the needs of these parties are not taken into account, because such parties do transact in spot markets. Speculators in futures markets take positions that ensure that futures prices reflect the information in spot markets (and vice versa). This interaction between spot and futures markets may provide incentives for exchanges to take the spot market into account in determining what precautions to take.
} 


\section{The Cargill Case}

The case of Cargill, Inc. v. Hardin 201 has been widely cited as one of "the model 'squeeze situations" 202 that is "part of the lore of the markets." 203 An analysis of Cargill, however, reveals the same conceptual confusion found elsewhere. What the court ultimately objected to was Cargill's exercise of market power. Therefore, its findings do not clarify the concept of manipulation in futures markets.

Cargill, Inc., was one of the largest grain merchandisers and exporters in the United States. ${ }^{204}$ In early I 963 , Cargill had hedged its inventory of soft red winter wheat by selling May 1963 wheat futures contracts on the Chicago Board of Trade. ${ }^{205}$ These contracts traded until May 2 I and could be satisfied at par by delivery of No. 2 soft red winter wheat. In February and March 1963 , Cargill sold substantial quantities of such wheat to mills in the southwestern United States and learned that the Spanish Government had indicated interest in purchasing soft red winter wheat. ${ }^{206}$ Because of these developments, Cargill concluded that supplies of wheat would be tight in May, liquidated its short position, and began to establish a long position in the May futures. ${ }^{207}$ Between April 15 and May 15, Cargill increased its long position to I,930,000 bushels, just short of the $2,000,000$ bushel position limit. ${ }^{208}$

On May I I, the Spanish Government offered to purchase 50,000 tons $\left(2,000,000\right.$ bushels) of soft red winter wheat. ${ }^{209}$ In response, Cargill offered on May I4 to sell I2,500 tons of wheat at $\$ 2.13^{1 / 2}$ per bushel, and on May I 5 Cargill offered to sell I 5,000 tons at $\$ 2.09$ per bushel. ${ }^{210}$ Both offers were accepted on May I 8. ${ }^{211}$ These sales and other commitments left Cargill with approximately 50,000 bushels of wheat on hand on May 20; others owned approximately 20,000 bushels. ${ }^{212}$

On May 20, Cargill placed an order to sell May 1963 contracts for I00,000 bushels of wheat at $\$ 2$. I9 (just below the highest permissible price), but it was able to sell only 40,000 bushels and the order was cancelled. ${ }^{213}$ At the opening of trading on May $2 \mathrm{I}$, the total open

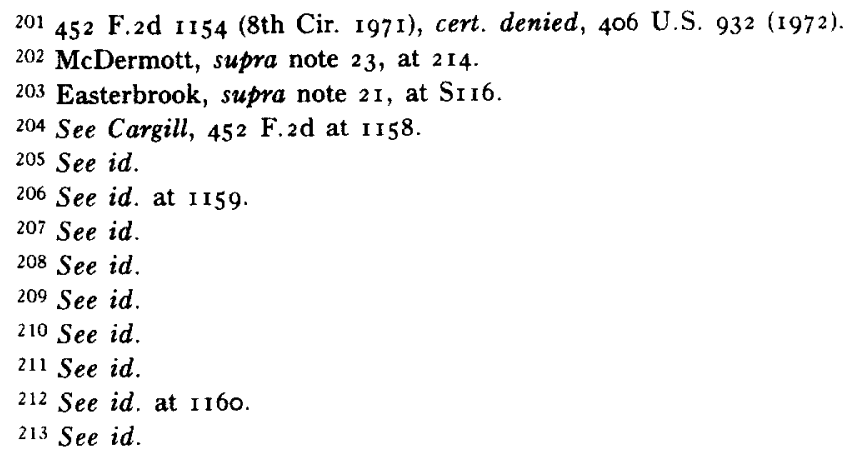


interest was approximately eight million bushels, of which Cargill owned I,890,000.214 At I I:45 a.m., the future was trading at $\$ 2.20$ and Cargill placed orders to sell its position at prices ranging from $\$ 2.27$ to $\$ 2.28 \frac{1}{4}$ (just below the maximum permissible price). ${ }^{215}$ Cargill's broker liquidated all but 365,000 bushels prior to the close of trading. ${ }^{216}$ During the settlement period, Cargill agreed to sell warehouse receipts to shorts at $\$ 2.28^{\frac{1}{4}}$, provided that the shorts redelivered the receipts to Cargill in satisfaction of their futures contracts. ${ }^{217}$ Cargill liquidated 315,000 bushels in this fashion and received 50,000 bushels from other sources. ${ }^{218}$ After settlement, Cargill had approximately 88,000 bushels of wheat, which it disposed of between June 4 and June 13 at prices ranging from $\$ 2$. IO to $\$ 2$. I3 per bushel. ${ }^{219}$

The Eighth Circuit based its conclusion that Cargill had manipulated the market price on four findings of fact: that Cargill acquired and held a controlling long position in the May i 963 wheat futures; ${ }^{220}$ that the shorts had an insufficient supply of wheat available (without coming to Cargill) for delivery on the futures; ${ }^{221}$ that Cargill obtained an artificially high price in liquidation of its futures contracts; ${ }^{222}$ and that the squeeze was intentionally caused by Cargill. ${ }^{223}$

The first finding is merely a statement that Cargill had market power - that is, the ability to control price. The second finding, however, amounts to the same thing. ${ }^{224}$ To reach this conclusion, the court found that supplies of hard wheat in Chicago and surrounding areas were properly excluded from the calculation of deliverable supply (even though hard wheat could be used to satisfy the delivery requirement of the futures contract) because "[i]t would be more economic to pay the long a premium than to pay the additional charges for premium wheat plus shipping and handling charges."225 But this is merely a finding that Cargill had market power; Cargill would have been unable to charge what it did for futures contracts if shorts could have obtained and delivered hard wheat for less.

\footnotetext{
$21+$ See id.

215 See id

216 See id

21 See id at I $160-61$

2 is See id. at I i6I.

217 See id.

$220 \mathrm{See} i d$ at 1164.

221 See id. It II67.

$\therefore 22$ See id. at 1169 .

223 See id. at I 72 .

$22+$ Note that the deliverable supply was insufficient to fulfill the contracts, even if it had been owned entirely by others. The court emphasized that Cargill alone knew that it owned a large fraction of the deliverable supply, see id. at 11 \% ownership would have averted the squeeze or affected the court's findings.

$2 ? 5$ Id. at $1 \mathrm{I} 66$.
} 
The court's finding that Cargill obtained an "artificial" price was based on evidence that the May 1963 prices were abnormally high compared to various historical benchmarks. ${ }^{226}$ As discussed earlier, ${ }^{227}$ such benchmark tests do not eliminate the possibility that unusual supply and demand conditions created abnormally high prices. The court did not recognize this, but it did conclude that Cargill caused the artificially high price because Cargill's sell orders were at prices of from seven to eight cents higher than what the future had been selling for. ${ }^{228}$ This latter finding distinguishes high prices caused by unusual supply and demand conditions from high prices caused by market power because it suggests that Cargill was able to "set the market price by reason of its dominant long position."229

Thus, none of the first three findings distinguishes Cargill's behavior from the profitable exercise of market power. Neither does the court's finding that Cargill intended to cause the squeeze. This finding was based primarily on the observation that Cargill's "behavior in liquidating its contracts was clearly intentional and was highly unusual market behavior; and the method of liquidating the unresolved open interest . . . was also unusual and clearly controlled by Cargill."230 But all this means is that Cargill tried to sell its position at the highest possible price. Because it had market power, it was able to do so.

None of the court's findings distinguish Cargill's purported manipulation from the profitable exercise of market power. Which of Cargill's transactions were manipulative? Perhaps the purchases of futures contracts between April 15 and May I5 were manipulative. But the court found that Cargill made these purchases because it had "concluded that supplies of wheat would be tight by . . . the end of the crop year" and that prices might rise. ${ }^{231}$ This is the essence of speculation. Perhaps it was Cargill's sales to the Spanish government that were manipulative. But these sales were at the market price and were publicly disclosed. Clearly these transactions, which allowed Cargill to obtain market power, were legitimate and normal market behavior. All that is left to criticize are Cargill's profit-maximizing sales at expiration. Monopoly theory is sufficient to analyze these; calling them a manipulation adds nothing.

226 See id. at 1167 .

227 See supra p. 546.

228 See Cargill, 452 F.2d at I $169-70$.

$229 \mathrm{Id}$. at $117 \mathrm{I}$

230 Id. at 1 I 70-71. The Court also discussed an inter-office telegram and an interview of a Cargill executive. This other evidence suggests that Cargill only believed it had the ability to influence prices at the time of expiration; the evidence does not show that Cargill intended to obtain such market power at the time it acquired its position.

231 Id. at 1159 . 


\section{CONCLUSION}

Manipulation is a fundamental concern of the regulation of financial markets. But manipulation is not defined in any of the regulatory statutes and, despite much academic and judicial commentary, no satisfactory definition of the term has been offered. The term is often used to refer to conduct that is better understood as something else - usually fraud or monopoly. In other cases, the term is used to refer to trading made with "bad intent" when the underlying transactions are otherwise indistinguishable from normal market activity. "Trading with bad intent" does provide the term "manipulation" with unique meaning, and such trading may be undesirable if manipulations do affect securities prices. However, there is no compelling reason to be concerned about such trading because it is likely to be self-deterring. For this reason, and because the enforcement of prohibitions is likely to be costly, actual trades should not be prohibited as manipulative regardless of the trader's intent. 
Copyright $@ 1991$ by The Harvard Law Review Association. Copyright of Harvard Law Review is the property of Harvard Law Review Association and its content may not be copied or emailed to multiple sites or posted to a listserv without the copyright holder's express written permission. However, users may print, download, or email articles for individual use. 